\title{
Functional cellulose-based hydrogels as extracellular matrices for tissue engineering
}

\author{
Sayan Deb Dutta ${ }^{1}$, Dinesh K. Patel ${ }^{2}$ and Ki-Taek Lim ${ }^{1 *}$ (D)
}

\begin{abstract}
Cellulose-based hydrogels are immensely important for tissue engineering. In this review, we attempt to document the source, nature, and application of cellulose-based hydrogels as an extracellular matrix for tissue growth and regeneration. Hydrogels can be prepared either from native cellulose, including both bacterial and plant sources or from cellulose derivatives, such as methyl cellulose, carboxymethylcellulose, and hydroxypropylmethylcellulose or even metal ions such as silver. Cellulose-polymer composite (polymers that include natural sources including chitosan, starch, alginates, collagen, hyaluronic acid, and chitin) are an attractive, inexpensive, and advantageous structural material that is easy to use. Cellulose-based scaffolding materials are widely used in the regeneration of various tissues, such as bone, cartilage, heart, blood vessel, nerve, and liver, among others. In this review, we discuss the most important applications of cellulosic hydrogels in tissue engineering based on their structural compositions.
\end{abstract}

Keywords: Cellulose, Hydrogels, Scaffolds, Extracellular matrices, Tissue engineering

\section{Introduction}

Cells communicate with each other either directly via molecular interactions or through the secretion of different hormones or mediators which systematically regulate various cell functions. Growth factors are also secreted during cellular crosstalk and may be pro-proliferative or anti-proliferative in nature, being mainly involved in cell differentiation, migration, adhesion, and gene expression. Natural and synthetic materials may be used as bulking agents for the binding of various growth factors by mimicking natural extracellular matrix (ECM) molecular self-assembly via secondary forces, such as ionic or hydrogen bonds, whereas chemical gels are result of covalent bonds [1-5].

Hydrogels have potential applications in various fields such as agriculture, food, biomaterials, water purification, biomedicine, and pharmaceuticals, among others. [6-8]. Hydrogels are primarily made up of natural living tissue rather than synthetic biomaterials, as a result have a high water content and a soft consistency similar to natural tissues [9]. Moreover, the high water content of these

\footnotetext{
* Correspondence: ktlim@kangwon.ac.kr

${ }^{1}$ Biorobotics Laboratory, Department of Biosystems Engineering, Kangwon

National University, Chuncheon, Republic of Korea

Full list of author information is available at the end of the article
}

materials contributes to their biocompatibility. Thus, hydrogels can be used as membranes for biosensors $[10,11]$, in artificial heart and skin $[12,13]$, contact lenses $[14,15]$, and drug delivery $[3,6,16]$. Crosslinking synthetic polymer-based hydrogels have been reported, including poly (ethylene glycol) [17, 18], poly (vinyl alcohol) [18, 19], poly (amido-amine) [20], poly (N-isopropylacrylamide) [21], polyacrylamide [18, $22]$, and poly (acrylic acid) [18, 23].

In tissue engineering, hydrogels are the most extensively used biopolymer due to their highly swollen three- dimensional (3D) environment, which is very similar to soft tissues and allows for the diffusion of nutrients, growth factors and cellular waste through the elastic network and for the regeneration of damaged tissues [13, 18, 24, 25]. In regenerative medicine, hydrogel used to repair and assist regeneration of various soft and hard tissues, such as cartilage, bone and vascular tissues [26-28]. Natural hydrogels include the bioprocessing of natural polymer-based materials such as proteins, including collagen, gelatin, and fibrin, and polysaccharides, including alginate chitosan, hyaluronic acid, dextran, and cellulose which are used as extracellular matrices (ECM).

Cellulose is a fibrous, tough, water-insoluble substance, found in the protective cell walls of plants, particularly in 
stalks, stems, trunks, and all woody portions. However, it is also produced by some animals (e.g., tunicates), fungi and a few bacteria [29-31]. Due to the presence of abundant hydroxyl groups in the cellulose molecule, cellulose can be used to prepare hydrogels with varying structures and properties to act as a platform for advanced tissue engineering and regenerative medicine. Cellulose-based materials represents a naturally occurring 'nanomaterial', and has attracted the attention of researchers all over the world, as shown by the increasing number of annual publications appearing in 'Science Direct' with 'cellulose-based hydrogels for tissue engineering' (Fig. 1) as the search item. However, furthur studies are needed for the development and application of cellulose-based hydrogels. This review highlights the recent development and use of various cellulose-based hydrogels as an ECM and their structural properties for applications in advanced tissue engineering.

\section{Structure of cellulosic biomass}

Cellulose is the most abundant biopolymer and is distributed throughout nature in plants, animals, algae, fungi, and minerals. A major source of cellulose is plant fiber. Cellulose is the main structural component of plants that provides them with their mechanical as well as structural integrity as it contributes approximately $40 \%$ to the carbon fraction in plants (Additional file 1: Table S1). Cellulose can be found in its pure form in plants with hemicelluloses, lignins, and other components [32]. Surprisingly, a large fraction of cellulose is produced from trees (wood fiber) with a global production of approximately 1,750,000 kt. Annual plants such as bamboo, cotton linters, jute, flax, sisal, hemp, and ramie also produces significant amount of cellulosic biomass (Additional file 1: Figure S1) [33]. In addition, some fungi and green algae produce cellulose (e.g. Valonia ventricular, Glaucocystis) and some marine ascidians contain cellulose in their outer cell membrane. Some bacterial genera, such as, Gluconacetobacter, Agrobacterium, Pseudomonas, Rhizobium, and Sarcina are able to synthesize bacterial cellulose either from glucose or other carbon sources [34-36]. Purified bacterial cellulose is highly crystalline and possess a high degree of polymerization (DP). One of the crucial features of cellulose is its micro-crystalline structure and its synthesis in nature as individual molecules (linear chain of glucosyl residues) which undergo self-assembly at the site of biosynthesis [37].

\section{Molecular structure of cellulose}

Cellulose mainly consist of D-glucopyranose ring units in a ${ }^{4} C_{1}$ configuration, which exhibits the lowest energy conformation [38]. Each unit is linked by $\beta-1,4$-glycosidic linkage that results in an alternate turning of the cellulose chain axis by $180^{\circ}$ [39-41]. Within the cellulose chain, three reactive hydroxyl groups $(-\mathrm{OH})$ exist in each anhydroglucose unit (AGU). The $-\mathrm{OH}$ groups of the AGU, the oxygen atoms of the D-glucopyranose ring, and the glycosidic linkage interacts with each other within the chain or another cellulose chain by intermolecular and intramolecular hydrogen bonds [42]. The presence of hydrogen bond provides stability to the cellulose molecule and allows it to be a functionally active biomolecule (Additional file 1: Figure S2).

X-ray diffraction studies revealed the crystalline structure of cellulose, and NMR experiments have confirmed its dimorphic and polymorphic nature [43, 44]. Different

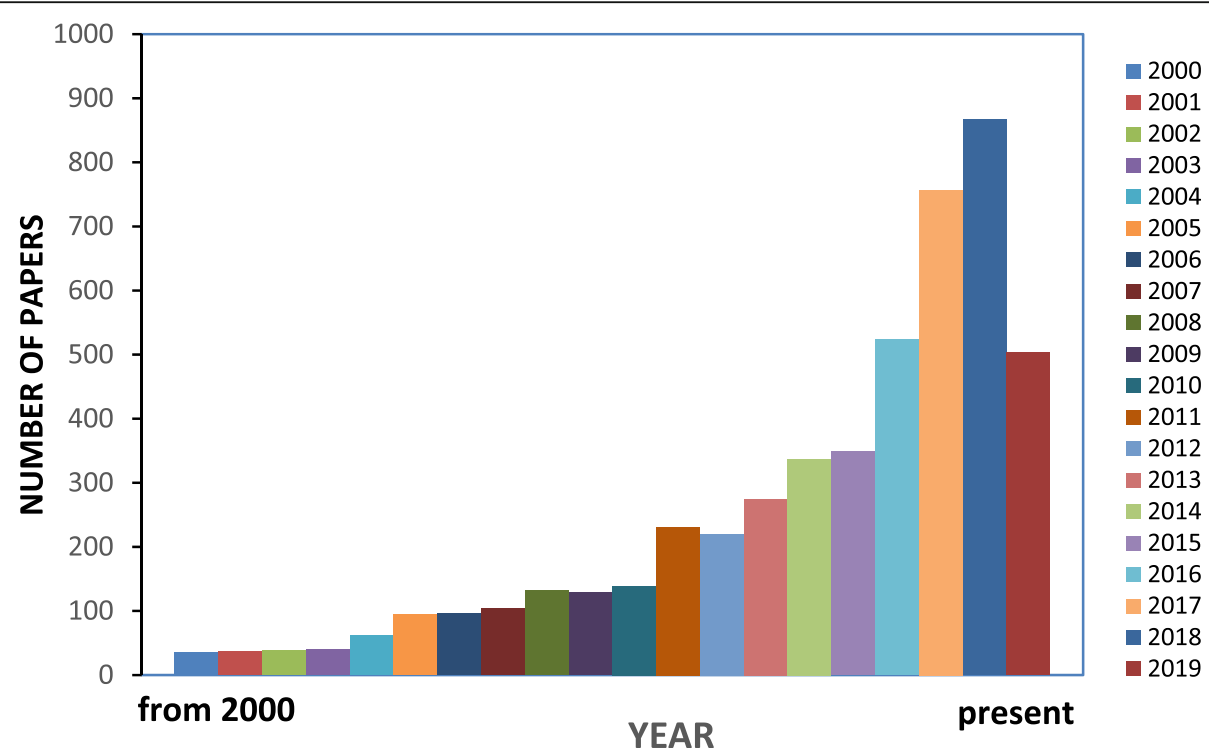

Fig. 1 Publications related to cellulose-based hydrogels for tissue engineering (science direct search system; 'cellulose based hydrogel for tissue engineering' as search term; https://www.sciencedirect.com) 
polymorphs of cellulose are listed in Table 1. Solid-state ${ }^{13} \mathrm{C}$-NMR was used to identify different polymorphs, denoted as cellulose $I_{\alpha}$ and $I_{\beta}$. Cellulose $I_{\beta}$ is naturally occurring in plants, whereas cellulose produced by primitive organisms crystallizes in the $\mathrm{I}_{\alpha}$ form [55].

Cellulose chains are arranged in a basic fibrillary unit or elementary fibrils with a length of 0.1 to $0.2 \mu \mathrm{m}$ and have a characteristic lateral dimension of $0.0015 \mu \mathrm{m}$ to $0.0035 \mu \mathrm{m}[56,57]$. Such fibrils are known as cellulose fibrils. These fibrils are further assembled into microfibrils with a width of $0.1 \mu \mathrm{m}$ and a length of 0.1 to $1 \mu \mathrm{m}$ (Fig. 2a). This fibrillary architecture can be found in both native and man-made fibers [39].

\section{Structure of plant cellulose (PC)}

In the case of plant cell walls, a sheath of amorphous cellulose surrounded by a hemicellulose layer covers the microfibrils [33]. Fibers from different plants vary in morphology and dimension. Additional file 1: Figure S3 clearly shows the variations in the fiber morphologies of cotton (S3a), spruce wood (S3b), and ramie plant (S3c). Surprisingly, all three plants share a common internal structure made up of multiple cell wall layers [58]. During the early growth phase, plant fibers develop a primary cell wall (P layer) that is much thinner than the secondary wall (S layer) formed on its inner side. Inside the $\mathrm{S}$ wall, a tertiary cell wall ( $\mathrm{T}$ layer) is present, which is typically an open, hollow area or lumen-like structure. The cell wall thickness and length of the plant fiber are approximately $4-630 \mu \mathrm{m}$ and $15-30 \mu \mathrm{m}$, respectively. The swelling characteristics as well as their physical and chemical properties are strongly influenced by the configuration, composition, and structure of the $\mathrm{P}$ layer, which contains microfibrils crisscrossed onto each other to make a net-like helical structure (S3d-e). The secondary layer is $3-5 \mu \mathrm{m}$ in thickness and comprises three sublayers
$\left(S_{1}, S_{2}\right.$, and $\left.S_{3}\right)$ of which $S_{2}$ is the thickest e (approximately 3-5 $\mu \mathrm{m}$ thickness) as shown in Additional file 1: Figure S3d. The $\mathrm{S}_{2}$ layer contains microfibrils arranged in parallel [58-60].

\section{Structure of bacterial cellulose (BC)}

Bacterial cellulose (BC) can be obtained in pure form. Compared to $\mathrm{PC}, \mathrm{BC}$ contains no hemicellulose or lignin and only a very small amount of carbonyl and carboxyl moieties are present [61]. BC possesses a high degree of crystallinity (above $80 \%$ ) with a good water retention capacity, and an extraordinary mechanical strength, particularly under wet conditions. One important advantage of using BC is its in-situ molding ability, i.e. shaping during biosynthesis [62]. The culturing and production of $\mathrm{BC}$ is the most important part, although it is also important to maintain the $\mathrm{pH}$ of the culture medium, since a low $\mathrm{pH}$ can often led to the accumulation by-products, such as of gluconic, acetic, or lactic acids [63]. Figure 2b clearly shows the structure and formation of bacterial cellulose in Acetobacter xylinum.

\section{Role of extracellular matrix (ECM)}

ECMs are used in tissue engineering and regenerative medicine as a natural model for bioactive modifications. Compared to other ECMs, hydrogels have provided opportunities for the use of a natural ECM as a model for designing biomimetic scaffolds.

\section{Structure and composition of ECM}

The tissues of the human body contain a significant amount of extracellular space, into which ECM molecules are secreted by cells to form a large and complex network. The ECM of the extracellular space provides tissue with mechanical strength, organizes cells into specific tissues,

Table 1 Polymorphs of cellulose

\begin{tabular}{|c|c|c|c|}
\hline Source & $\begin{array}{l}\text { Cellulose } \\
\text { polymorphs }\end{array}$ & Features & References \\
\hline $\begin{array}{l}\text { Valonia ventricosa } \\
\text { (bubble algae) } \\
\text { Acetobacter xylinum } \\
\text { (bacteria) } \\
\text { Microdictyon (green algae) } \\
\text { Halocynthia (tunicates) }\end{array}$ & Cellulose I & $\begin{array}{l}\text { Native cellulose, found in nature, interconvertible, stable. Crystalline forms are } \\
\text { termed as } I_{\alpha} \text { and } I_{\beta} \text {. } I_{a} \text { considered as primitive type, while higher plants possess } I_{\beta} \text {. }\end{array}$ & $\begin{array}{l}\text { Marchessault } \\
\text { and Sarko, } 1967 \\
{[45]} \\
{[46]} \\
{[47]} \\
{[48]}\end{array}$ \\
\hline $\begin{array}{l}\text { Halicystis (green algae) }{ }^{2} \\
\text { Mutant strain of A. xylinum }\end{array}$ & Cellulose II & Obtained from cellulose I, interconvertible, also found in nature. & $\begin{array}{l}{[49]} \\
{[50]} \\
{[51]} \\
\text { Kuga et al., } \\
1993 \text { [52] }\end{array}$ \\
\hline $\begin{array}{l}\text { Chemical conversion of Valonia } \\
\text { cellulose I and cellulose II }\end{array}$ & Cellulose III & $\begin{array}{l}\text { Interconvertible and not found in nature. Two crystalline forms isolated as }\|\|_{\mid} \text {and } \\
\|\|_{\|} \text {respectively. }\end{array}$ & $\begin{array}{l}{[49]} \\
{[50]}\end{array}$ \\
\hline $\begin{array}{l}\text { Chemical conversion and } \\
\text { heating of cellulose }\|\|_{\mid} \text {and } \mid \|_{\|}\end{array}$ & Cellulose IV & $\begin{array}{l}\text { Interconvertible and not found in nature. Two crystalline forms isolated as } I_{1} \text { and } \\
I_{\|} \text {respectively. }\end{array}$ & $\begin{array}{l}{[53]} \\
{[54]}\end{array}$ \\
\hline
\end{tabular}

${ }^{1}$ highly crystalline cellulose obtained from Valonia

${ }^{2}$ naturally occurring cellulose II 

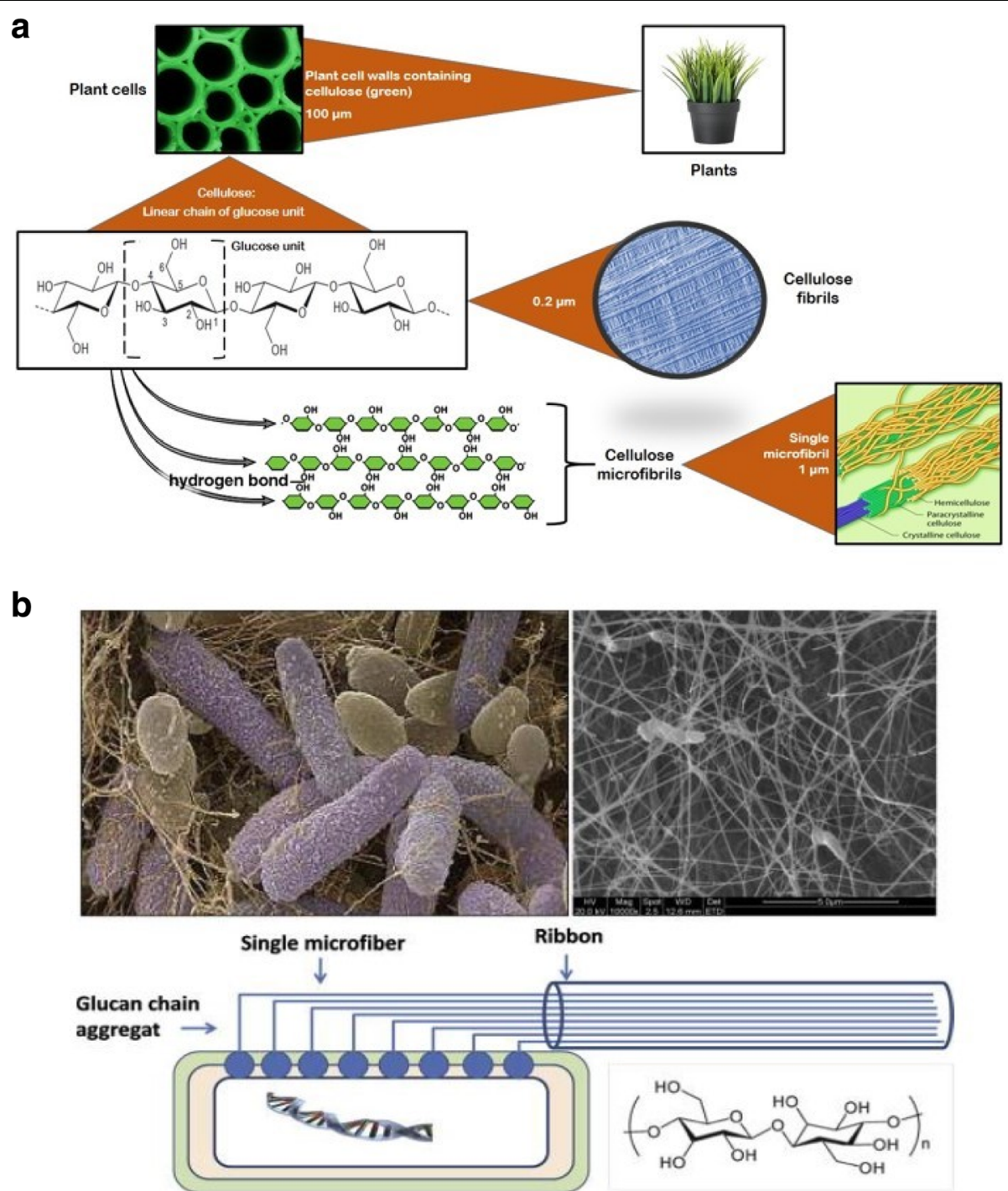

Fig. 2 Structure of cellulose and bacterial cellulose. a structure of cellulose fibrils $(0.2 \mu \mathrm{m})$ and microfibrils $(1 \mu \mathrm{m})$; b SEM images of Acetobacter xylinum and formation of bacterial cellulose [53] SEM: Scanning electron micrograph

and controls cell behavior and cell differentiation. Two crucial components of the ECM are proteins and glycans, in particular fibrous proteins (e.g., collagen, laminin, and elastin) and glycosaminoglycans (GAGs) [64, 65]. Fibrous proteins act as a scaffold and provide adhesion to matrix structure that are initially embedded in GAGs [65]. Thus, cell-matrix adhesions mediate various physiological responses including cell growth, migration, differentiation, survival, tissue organization and matrix remodeling [66].

\section{Function of ECM}

The ECM components undergo self-assembly to form a complex 3D network [18]. Figure 3 shows the role of ECMs in various cellular responses. Cell receptors bind both soluble and tethered signaling cues from the ECM environment. In turn, these receptor-ligand interactions trigger complex cascades of intracellular enzymatic reactions that regulate gene and protein expression and define the fate of a cell in a specific tissue $[18,66]$. Cell can also transmits a signal to actively construct and degrade their microenvironment. Thus, the ECMs acts as both a space-filling mechanical scaffold and a bioactive and dynamic environment to mediate cellular functions [64, 65]. However, natural ECMs also provide cellular adhesion, proteolytic degradation and growth factor (GF)- binding [18].

\section{Basic properties of hydrogels}

Hydrogels are a type of polymer biomaterials with various properties. In the field of pharmaceutical and biomedical engineering, hydrogels are very important due to their in-vivo swelling properties, mechanical strength 


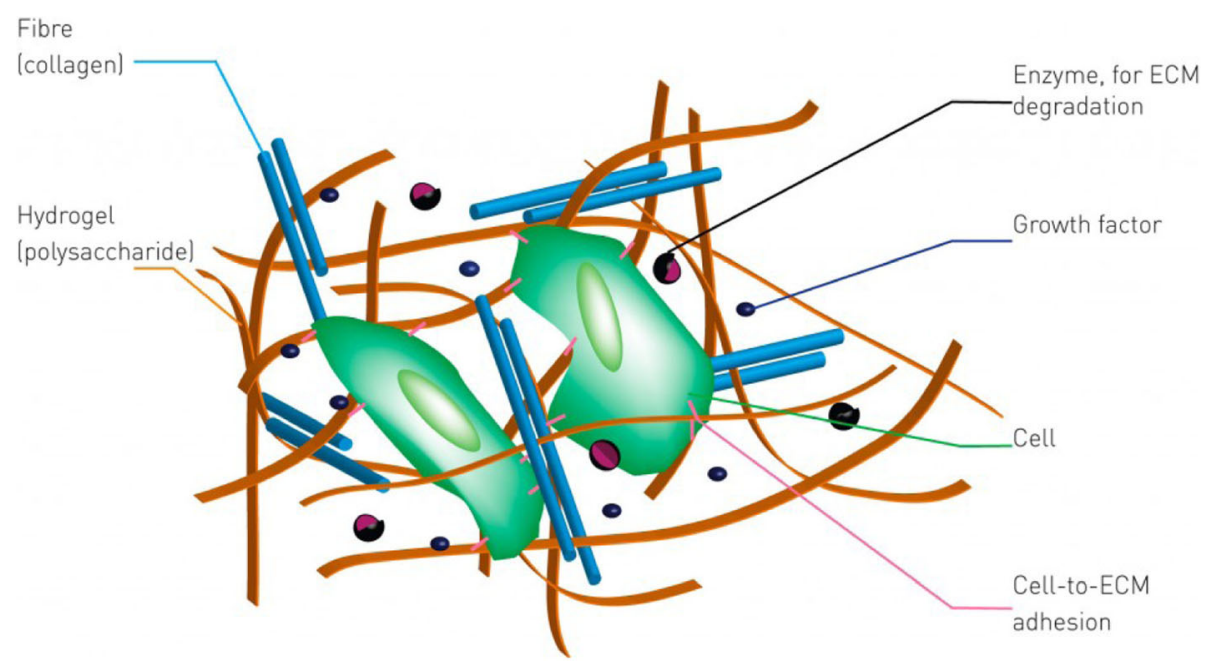

Fig. 3 Schematic representation of the extracellular matrix (ECM). In a natural environment, cells (green) use specific markers (pink) to bind to a mechanical support matrix of polysaccharides or hydrogel (yellow) and fibrous proteins (blue). Dissolved proteins like growth factors (purple) enable communication between the cells and matrix-degrading enzymes (black), thus remodeling the matrix [67]

and compatibility with biological tissues, facilitating binding (Fig. 4) [68-70].

\section{Mechanical properties}

The mechanical properties of hydrogels are significant from both a pharmaceutical and biomedical point of view [68]. The optimum mechanical strength of a hydrogel is an essential requirement for its successful implementation as a drug delivery system. The excellent mechanical properties of hydrogels allows its physical integrity to be maintained until the cargo molecules are released at a predetermined rate for a predetermined time. The optimum degree of cross-linking may lead to a hydrogel with a suitable mechanical strength. However, by increasing the degree of cross-linking, a stronger form of the hydrogel can be prepared, such as brittle hydrogel that exhibits a decreased percentage of elongation $[68,71]$.

\section{Swelling properties}

Hydrogels are polymer-based biomaterials developed by the physical or chemical linking of polymers. When hydrogels are exposed to water, they can absorb the water or aqueous

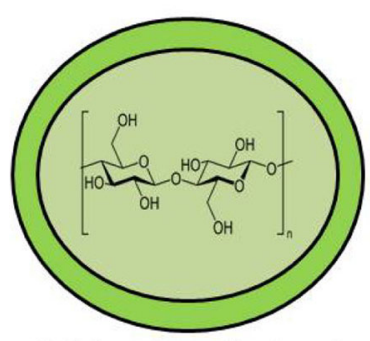

Cellulose-based hydrogel

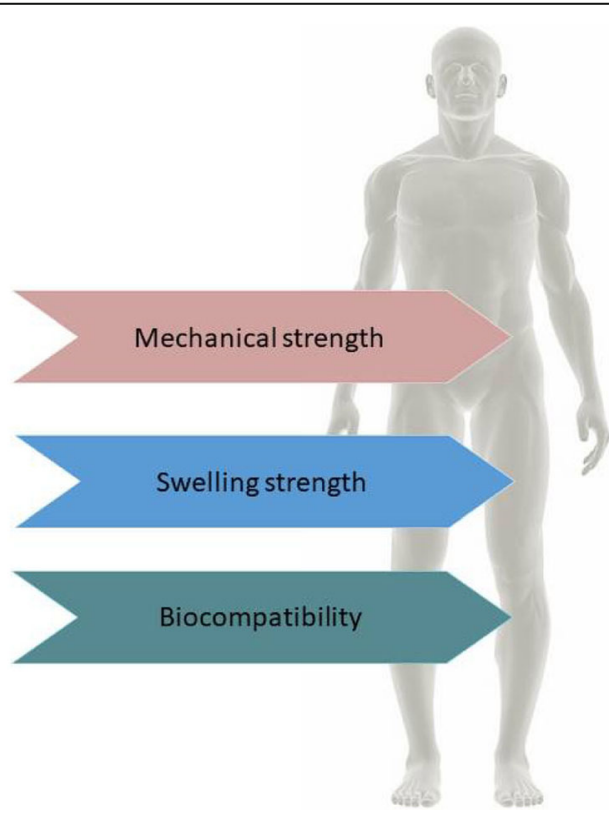

Fig. 4 Advantages of the use of cellulose-based hydrogels for tissue engineering 
fluids without dissolving. This swelling continues until there is an equilibrium between the water and the polymer is established. On the other hand, the elasticity of this biomaterial results from the polymer-polymer interactions that prevent the water flux inside the hydrogel resulting in a state known as "equilibrium swelling" [72].

\section{Biocompatibility}

In the case of tissue engineering and regenerative medicine, hydrogels must be compatible and non-toxic. Biocompatibility is a process that deals with the ability of a hydrogel to perform an appropriate host response in a specific application. Biosafety and bio-functionality are the two keys factors regulating biocompatibility [73]. Polysaccharide-based hydrogels are strikingly important among the polymer hydrogels due to the variety of chemical structures and functional properties [74, 75]. Hydrogels also act as reversible gels with enlargements, such as ionic, $\mathrm{H}$-bonding, or hydrophobic forces which play a crucial role in forming the network [76-78]. The extensive use of hydrogels in the biomedical field is a direct result of their capacity to hold high amount of water, elasticity, biocompatibility, and non-toxicity, among others. The swelling properties of hydrogels results from the presence of hydrophilic groups, such as, $-\mathrm{OH},-\mathrm{COOH},-\mathrm{CONH}_{2}$, and $-\mathrm{SO}_{3} \mathrm{H}$ in polymer chains [79]. Swelling is a crucial property of hydrogels for use in biomedical applications, such as in wound dressings [80].

\section{Cellulose-based hydrogel production}

The production of cellulose and cellulose-based hydrogel has many advantages in the biomedical and pharmaceutical industries [76]. In addition to plant cellulose (PC) production, microbial cellulose (MC; also known as bacterial cellulose or $\mathrm{BC}$ ) production is of great importance and is normally carried out using Gram-negative bacteria, such as Acetobacter xylinum [81]. Other bacteria used to produces cellulose are listed in Table 2. Bacterial cellulose is produced using either static or shaking culture methods. However, the shaking culture method is more effective than the static culture method; due to the increased growth of bacteria and the high cellulose yield (Fig. 5) [90]. One of the essential features of bacterial cellulose $(\mathrm{BC})$ is the presence of a fine microfibrillar structure that is entirely responsible for its high tensile strength, high crystallinity index, and high degree of polymerization. A previous study found that a hydrogel obtained from BC $(0.8 \%)$ had a good biocompatibility for use in tissue remodeling[91]. The study also showed the high degree of crystallinity of BC around 89\% [92], a high degree of polymerization [93], and a high specific surface area $\left(37 \mathrm{~m}^{2} / \mathrm{g}\right)$ [94]. Again, BC also showed a large surface area, high aspect ratio, and low bulk density, as well as hydrophilicity [76]. For this reason, BC is widely used in healthcare and medicinal research [95].

\section{Processing of cellulose-based hydrogels}

Various methods have been employed for the production and processing of hydrogels based on cellulosic materials. Hydrogels can be obtained either directly from native cellulose or from cellulose derivatives [96]. A list of cellulose derivatives, and their solvents, and processing methods is presented in Table 3.

\section{Hydrogels obtained from native cellulose}

A cellulose-based hydrogel can be obtained from a cellulose solution through physical cross-linking. Due to the presence of hydroxyl groups in cellulose, it can easily form cross-linking through hydrogen bonding. The highly extended hydrogen-bonded structure of cellulose results in a compact such that it is not easily dissolved in common solvents [113]. Various solvents have been used to dissolve cellulose. Nowadays, new solvents, such as $\mathrm{N}$-methylmorpholine- $\mathrm{N}$-oxide (NMMO), ionic liquids (ILs), and alkali/ urea (or thiourea) aqueous systems have been developed to dissolve cellulose, with important applications in hydrogel research. However, certain bacterial species are involved in the processing of nearly-pure cellulose hydrogels [96]. Many solvent systems are used to obtain hydrogels

Table $\mathbf{2}$ List of some bacteria producing cellulose

\begin{tabular}{|c|c|c|c|}
\hline Type of bacteria & Example & Application & References \\
\hline \multirow[t]{9}{*}{ Gram-negative } & Acetobacter xylinum & Tissue repair material, human tissue substitute or artificial skins; wound dressing & [81]; [82]; [83]; [84] \\
\hline & Gluconacetobacter hansenii & Medical pads, artificial skins & [85] \\
\hline & Acetobacter pasteurianus & Medical pads, membranes & [86]; [87] \\
\hline & Rhizobium sp. & Tissue repair material & [82]; [88] \\
\hline & Agrobacterium sp. & Tissue repair material & [82]; [88] \\
\hline & Aerobacter sp. & Tissue repair material & [88] \\
\hline & Azotobacter sp. & Tissue repair material & [88] \\
\hline & Salmonella sp. & Tissue repair material & [88] \\
\hline & Achromobacter sp. & Tissue repair material & [88] \\
\hline Gram-positive & Sarcina ventriculi & Cell culture, tissue engineering, regenerative medicine & [82]; [88]; [89] \\
\hline
\end{tabular}




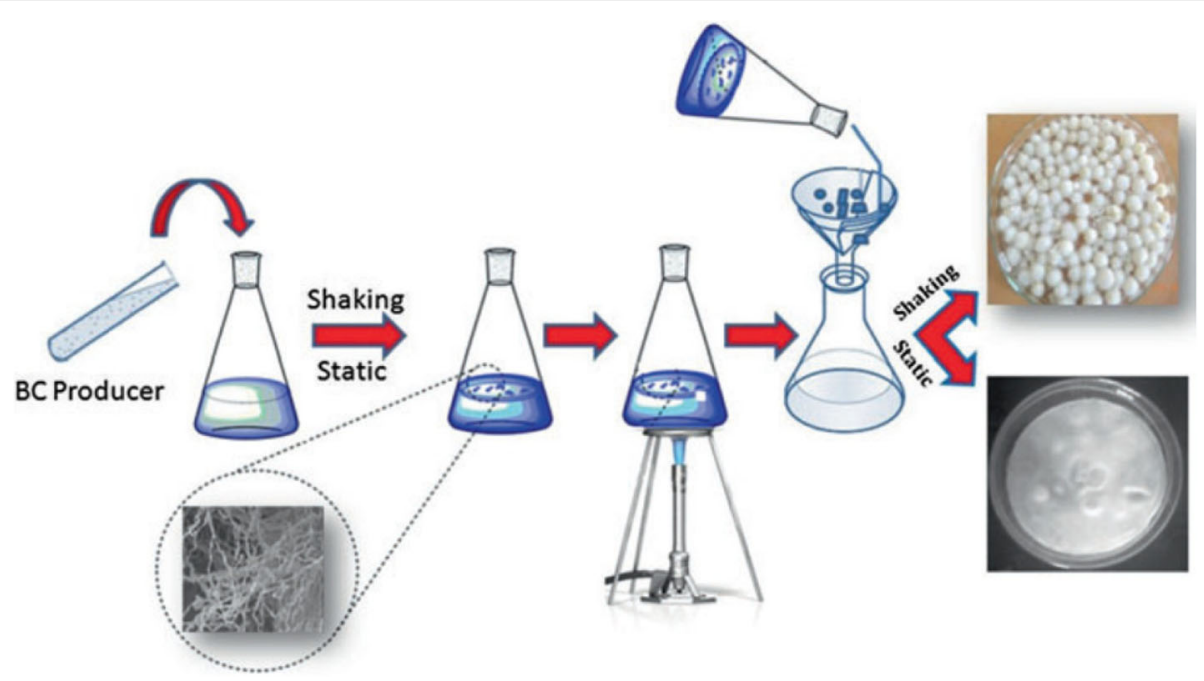

Fig. 5 Schematic representation of strategy for BC production [73] BC: bacterial cellulose

from native cellulose. One such systems involves the use of $\mathrm{LiCl} / \mathrm{DMAc}$ which consists of a mixture of 3 to $15 \%$ lithium chloride/LiCl (w/w), dimethylacetamide/DMAc, and 1-methyl-2-pyrrolidinone under specific temperature conditions (normally less than $150^{\circ} \mathrm{C}$ ) [114]. Cellulose is then dissolved in amide and $\mathrm{LiCl}$ in the absence of any polar medium other than amide to obtain hydrogels. However, [99] described the processing of cellulose hydrogels in bead form via the dropwise addition of cellulose solution into DMAc and $\mathrm{LiCl}$ to azeotropic methanol or isopropanol as a non-solvent (Fig. 6a). The size of the beaded hydrogels obtained from this method may varies from 100 to $1500 \mu \mathrm{m}$ [99]. In the $\mathrm{LiCl} / \mathrm{DMAc}$ system, the cellulose concentration has been determined to be $7 \mathrm{wt} \%$. The presence of water in the cellulose solution is a critical factor for hydrogel production [96]. There have been reports of the rapid dissolution of cellulose at room temperature (around $25^{\circ} \mathrm{C}$ ) using solvent system with a mixture of dimethylsulfoxide/tertrabutylaluminium fluoride trihydrate (DMSO/TBAF) [116]. Due to its ability to form hydrated dipoles in aqueous solution, TBAF is considered as a suitable solvents for cellulose.

The NMMO solvent system also provides a method for the production of regenerated cellulose fibers, films, food casings, membranes, sponges, and beads, among others without the formation of hazardous byproducts

Table 3 Summary of some cellulose derivatives and its corresponding hydrogel processing methods

\begin{tabular}{|c|c|c|c|c|}
\hline Cellulose/cellulose derivatives & Nature of solvents & $\begin{array}{l}\text { Solvent } \\
\text { systems }\end{array}$ & Corresponding hydrogels preparation methods & References \\
\hline Cellulose form wood & Polar solvents & $\mathrm{NMMO}$ & Solution polymerization at $85^{\circ} \mathrm{C}$ & [97] \\
\hline Cellulose from cotton pulp & Polar solvents & $\mathrm{LiCl} / \mathrm{DMAC}$ & Solution polymerization at $75-90^{\circ} \mathrm{C}$ & [98]; [99]; [100] \\
\hline Filter paper & lonic solvents & {$[\mathrm{Amim}] \mathrm{Cl}$} & Solution polymerization at $70^{\circ} \mathrm{C}, 2 \mathrm{~h}$ & ([101]; [102]) \\
\hline Tunicate cellulose & $\begin{array}{l}\text { Alkali aqueous } \\
\text { systems }\end{array}$ & Alkali/urea & Polymerization at -12 to $-10^{\circ} \mathrm{C}, 5-10 \mathrm{~min}$ & [103] \\
\hline Cotton linter & $\begin{array}{l}\text { Alkali aqueous } \\
\text { systems }\end{array}$ & $\begin{array}{l}\text { Alkali/ } \\
\text { thiourea }\end{array}$ & Polymerization at $-5^{\circ} \mathrm{C}, 2-10 \mathrm{~min}$ & [104] \\
\hline $\begin{array}{l}\text { Carboxymethylcellulose } \\
\text { (CMC) }\end{array}$ & Polar solvents & $\mathrm{H}_{2} \mathrm{O}$ & Solution polymerization, In situ polymerization & $\begin{array}{l}{[105] ;[106] ;} \\
{[107]}\end{array}$ \\
\hline Methyl cellulose (MC) & Polar solvents & DCM/DMSO & Solution polymerization, In situ polymerization & $\begin{array}{l}{[106] ;[108] ;} \\
{[109]}\end{array}$ \\
\hline Hydroxyethyl cellulose (HEC) & Polar solvents & $\mathrm{H}_{2} \mathrm{O}$ & Solution polymerization, cryogenic treatment & {$[106] ;[110]$} \\
\hline $\begin{array}{l}\text { Hydroxypropyl methyl cellulose } \\
\text { (HEMP) }\end{array}$ & Polar solvents & $\mathrm{H}_{2} \mathrm{O} /$ ethanol & $\begin{array}{l}\text { Solution polymerization, inverse-phase suspension } \\
\text { polymerization }\end{array}$ & [106]; [111] \\
\hline Cellulose acetate (CA) & Polar solvents & Acetone/ $\mathrm{H}_{2} \mathrm{O}$ & Chemical cross-linking & [112] \\
\hline
\end{tabular}

NMMO N-methylmorpholine- $\mathrm{N}$-oxide, LiCl/DMAC Lithium chloride/dimethylacetamide, [Amim] Cl 1-allyl-3-methylimidazolium chloride, $\mathrm{H}_{2} \mathrm{O}$ water, $\mathrm{DCM} / \mathrm{DMSO}$ Dichloromethane/dimethyl sulfoxide 

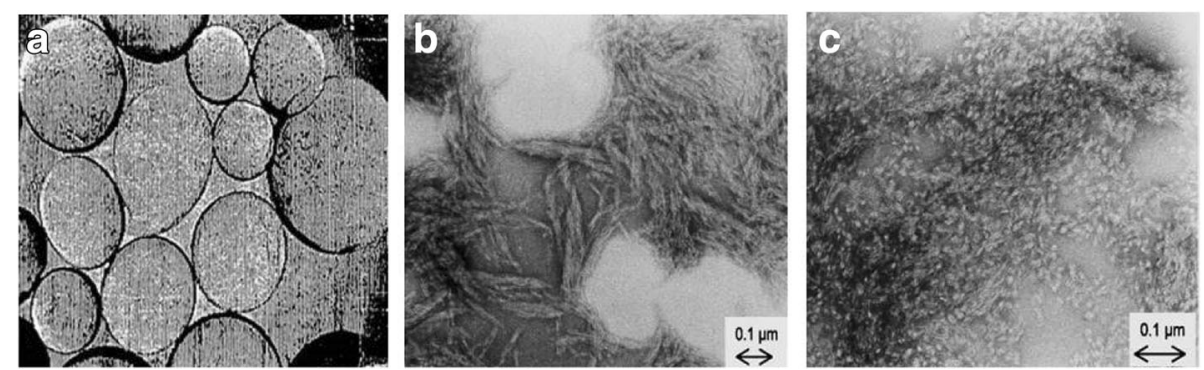

Fig. 6 a Cellulose hydrogel beads with an average size of $467 \mu \mathrm{m}$ [99], b NMMO fibers, c Viscose fibers [115] NMMO: N-methylmorpholine-N-oxide

from cellulose solution [115]. Fiber formation occurs in a dry jet-wet spinning process, taking into account several physical factors (e.g. nozzle and air-gap dimensions, drew-down ratio, take-up speed) and dopinge characteristics (cellulose DP and concentration, temperature, modifiers) which influence the shaping process and the final fibers properties. Tertiary amine oxides are also capable of dissolving up to $10 \%$ cellulose [117]. A novel method has been developed which produces highly concentrated cellulose, up to $23 \%$, by treating cellulose with NMMO and water [118]. The cellulose fibers generated using the NMMO system are of two types: NMMO fiber and viscose fiber. The NMMO fiber is typically round/ oval, homogenous/dense, highly amorphous, and crystalline, as shown in Fig. 6b. On the other hand, viscose fibers are lobate, less homogenous, and more or less amorphous, as indicated in Fig. 6c [119].

Ionic liquids (ILs) also served as a suitable solvent for cellulose and cellulosic materials. Hydrophilic ILs, such as 1-butyl-3-methylimidazolium chloride (BMIMCl) and 1-allyl-3-methylimidazolium chloride (AMIMCl) are commonly used to dissolve cellulose at room temperature (around $25^{\circ} \mathrm{C}$ ) $[120,121]$. After treatment with AMIMCl, regenerated cellulose exhibited excellent mechanical properties. Thus, room temperature ILs represents a new and versatile platform for the comprehensive utilization of cellulose resources and the manufacturing of novel cellulose-based materials with unique properties [121].

Similar to ILs, a cellulose solvent with fast dissolution was developed using a mixture of precooled $\left(-12^{\circ} \mathrm{C}\right) 7$ wt $\% \mathrm{NaOH}$ and $12 \mathrm{wt} \%$ urea aqueous solution [[103, 122, 123] in]. Native cellulose dissolved within 2 min in $\mathrm{NaOH} /$ urea solution. Thus, this alkali/urea solvent system provides a rapid and convenient method for the rapid-rate dissolution of cellulose.

\section{Hydrogels obtained from cellulose derivatives}

Water-soluble cellulose derivatives are generally biocompatible, and can therefore be used as thickening agents, binding agents, emulsifiers, film formers, suspension aids, surfactants, lubricants, and stabilizers, and in particular as additives in the food, pharmaceutical, and cosmetic industries. Selective cellulose derivatives, including methyl cellulose (MC), hydroxypropyl cellulose (HPC), hydroxypropylmethyl cellulose (HPMC), and carboxymethyl cellulose (CMC) have been used to fabricate cellulose-based hydrogels through physical and chemical cross-linking. In the case of physically cross-linked gels, no covalent bonding formation or breakage takes place, and the crosslinked network is formed through ionic bonding, hydrogen bonding, or an associative polymer- polymer interaction [96]. On the other hand, chemical cross-linked hydrogels are prepared through cross-linking two or more kinds of polymer chains either with a functionalized cross-linker [124] or under UV irradiation [125]. Physically cross-linked hydrogels are widely used in different biomedical fields, including as scaffolds for cell cultures, in cartilage models, and as implants in bone defects [126].

Silated-hydroxypropylmethyl cellulose (Si-HPMC) hydrogels are generally developed for use as scaffold in 3D cultures of osteogenic cells, and are suitable for both in vivo injection and in vitro culturing. However, a previous study presented the use of Si-HPMC hydrogels in osteoblastic survival, proliferation, and differentiation when used as a new scaffold and provided a new treatment technique after bone replacement surgery [127]. MC hydrogels are widely used to mount the surface of polystyrene dishes and are used to cultivate human embryonic stem cells (hESCs) for the formation of embryonic bodies (EBs) in liquid suspension cultures [96, 128, 129]. The EBs developed from the hESCs are shown to express molecular markers specific for representative cells from the three embryonic germ layers, indicating the use of MC-coated dish for the large-scale production of EBs from hESCs as shown in Fig. 7a-c.

\section{Mixed hydrogels}

The mixing or blending of different polymers, such as, a cellulose-polymer composite is a desirable, inexpensive and advantageous method for obtaining novel structural materials [6]. Cellulose (or its derivatives) blended with natural biodegradable polymers, such as chitin, chitosan 
[130], starch [131, 132], alginates [133, 134], and hyaluronic acid [135], has been used to created novel materials for specific applications. Some examples include the blending of a cellulose-polymer composite with chitosan for the removal of heavy metals, with starch for the food industry, and with alginates for tissue engineering [Chang, 2011].

Cellulose-chitosan hydrogel beads areprepared by blending cellulose powder to chitosan solution [136]. Chitosan is perviously blended with a highly concentrated carboxymethylated cellulose solution to form physical hydrogels, which is then cross-linked by irradiation [137]. This cellulose-chitosan duplex has been shown to exert non-diffusible antibacterial properties $[128,129]$. A novel microporous hydrogel produced by mixing of cellulose with sodium alginate (SA) solution and then cross linking with epichlorohydrin. The final cellulose/SA hydrogels were characterized by solid-state, ${ }^{13} \mathrm{C}$ NMR, wide-angle X-ray diffraction (WXRD), thermo-gravimetric analysis (TGA), scanning electron microscopy (SEM), rheological measurement, dynamic mechanical analysis (DMA), and swelling test analyses to evaluate the structure and morphology of the hydrogels (Fig. 8a-c) [138].

Currently, polymeric-inorganic hybrid compounds have been widely used in various fields, such as electrical, optical, magnetic, and biological fields, among others [138]. A novel method for the incorporation of inorganic materials and cellulose hydrogels has been studied in New Zealand white rabbits with criticallysized bone defects in the distal femoral epiphyses [139]. In the experimental process, the researchers used an injectable and self-cross-linkable bone substitute (IBS2) composed of Si-HPMC viscous solution (3wt\%) in alkaline medium, supplemented with biphasic calcium phosphate $(\mathrm{BCP})$ ceramic particles. The diameter of the $\mathrm{BCP}$ particles ranged from 40 to $80 \mu \mathrm{m}$. After a number of weeks, centripetal bone formation was observed near the defects, with a yield strength that was significantly higher than that of the host trabecular bone tissue.

\section{a}
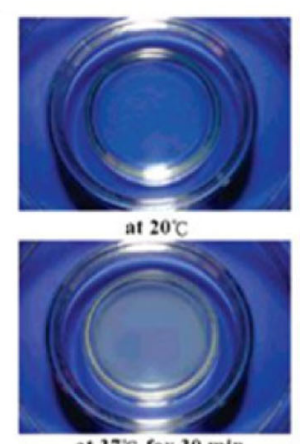

at $37 \mathrm{r}$ for $30 \mathrm{~min}$

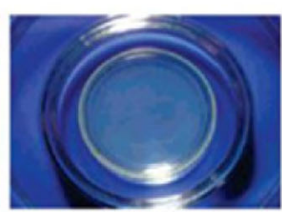

at $37 \mathrm{C}$ for $15 \mathrm{~min}$

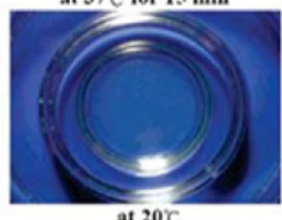

b

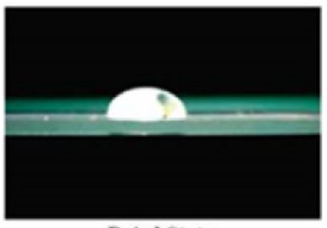

Dried State

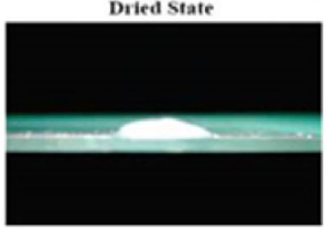

LSC-MC/PS
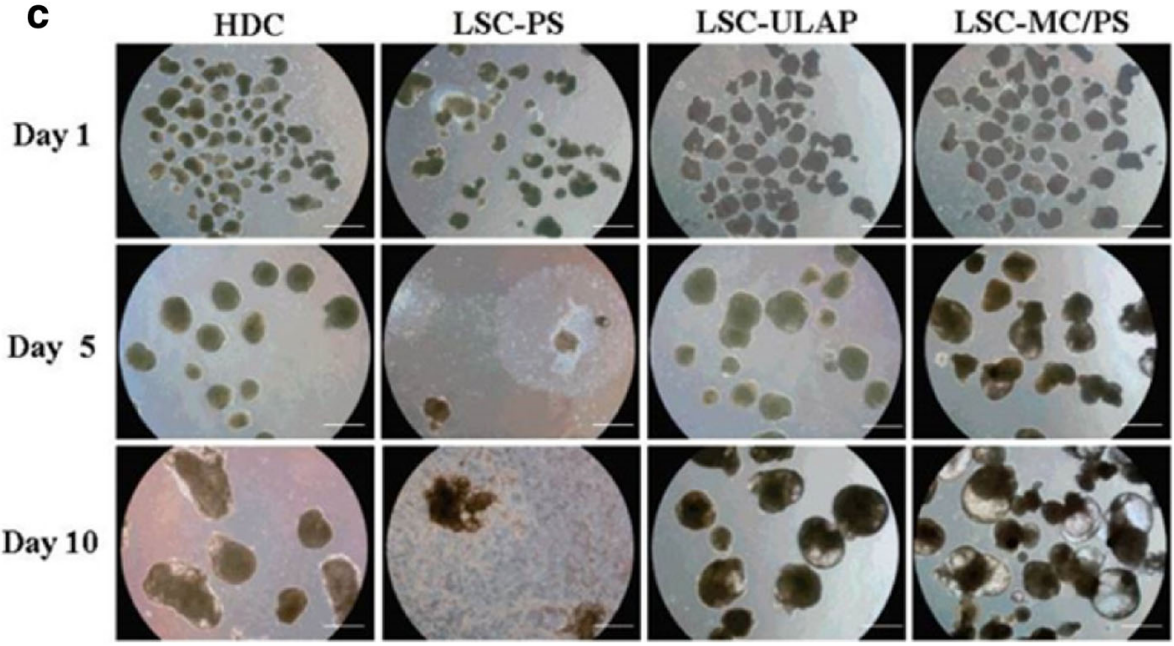

Fig. 7 MC-coated hydrogel dishes for hESCs differentiation. a Original photograph s of the MC Hydrogel-coated in a polystyrene dish at distinct temperatures; b Photograph of a water drop on the surface of the MC hydrogel coated in a polystyrene dish in the dried or hydrated state; $\mathbf{c}$ Photomicrographs of the hESCs cultivated by different methods for distinct periods (magnification 40x). MC: methyl cellulose; hESCs: human embryonic stem cells; HDC: hanging drop culture; LSC-PS: liquid suspension culture in polystyrene dish; LSC-ULAP: liquid suspension culture in the Corning Ultralow Attachment plate; LSC-MC/PS: liquid suspension culture in the MC-coated polystyrene dish. Scale bars, 1.0 mm [124, 134] 

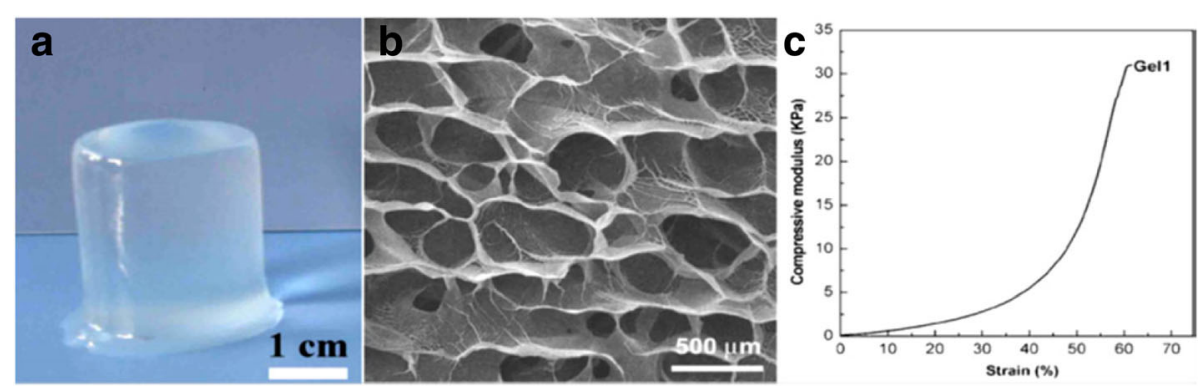

Fig. 8 Original photograph (a), SEM image (b), and compressive stress-strain curve (c) of cellulose/SA hydrogel [139] SEM: scanning electron microscopy; SA: sodium alginate

Figure 9a-c shows how bone regeneration occurs after the application of Si-HPMC/BCP materials. The use of BC from Gluconacetobacter hansenii along with a novel composite material composed of calcium-deficient hydroxyapatite (CdHAP) for orthopedic use has been well characterized and described by [140]. On the other hand, [141] reported the use of heparin/cellulose/charcoal composites to understand the mechanism and crosstalk among cells. To study intracellular drug delivery systems and cellular proliferation, single-walled carbon nanotubes (SWCNTs) wrapped with cellulose have been observed in HeLa cells [101, 102]. Researchers developed SWCNTs with a cellulose solution, dissolved in ionic liquid 1-butyl-3-methylimidazolium bromide (Fig. 9d-e). Another study showed that long cellulose/SWCNT scaffolds could promote the growth of HeLa cells, whereas short cellulose/SWCNT were found to only have a small effect on cell proliferation of HeLa cells (Fig. 9f-h). Healthy cells have a green nucleus, uniform chromatin, and an intact cell membrane, whereas necrotic cells or late apoptotic cells have red nuclei with damaged cell membranes. Cells cultured on a composite scaffold and a glass slide are healthy with a green nucleus (Fig. If and h), however, some cells culture on purified SWCNTs are in the late apoptotic stage (Fig. 9g). Thus, inorganicbased cellulosic hydrogels provide a wide range of applications in the biomedical and tissue engineering field.

\section{Application of cellulose hydrogels in tissue engineering}

Cellulose-based hydrogels are used in different fields related to tissue engineering. Patterned macroporous (PM) with a diameter larger than $100 \mu \mathrm{m}$ were introduced to pristine 3D nanofibrous BC scaffolds using infrared (IR) micromachining techniques to create an in vitro culture model for breast cancer cells (BCs) [142]. PM-BC scaffolds were found to be promote cellular adhesion, growth, proliferation, and infiltration of BCs. A. xylinum BC also promotes wound healing as it maintains the wound moist by controlling the wound exudates and also heals severe second-degree burns [143, 144]. Hydroxyethylcellulose
(HEC) and carboxymethyl cellulose sodium salt (CMCNa) cross-linked with hyaluronic acid allow for the proliferation of keratinocytes in an in vitro culture [144]. Bacterial nanocellulose (BNC) has great potential for use as a scaffold in tissue engineering, since $\mathrm{BC}$ is more effective than $\mathrm{PC}$, which accounts for $\mathrm{BC}$ being the first choice in medical and tissue engineering applications.

\section{BC hydrogels in biomedical applications}

$\mathrm{BC}$ has promising features due to the similar of its nanostructure and morphology to collagen making $\mathrm{BC}$ an attractive choice for use in the support and immobilization of cells. The architecture of $\mathrm{BC}$ materials can be engineered at range of scales, ranging from the nano to macroscale by controlling the biofabrication process. $\mathrm{BC}$ fibers are solid and, when used in combination with other biocompatible materials, produce nanocomposites particularly suitable for use in human and veterinary medicine [76]. The applications of $\mathrm{BC}$ composite hydrogels in biomedicine and tissue engineering are listed in Table 4. BC composites can also be used in cornea formation after cornea surgical treatment, as well as heart and vascular tissue regeneration [148].

\section{Bioactive cartilage implantation}

Since, BC gels are free from the action of proteolytic enzymes and reactive oxygen species (ROS), they protects the body from carcinogenesis and prevents the appearance of inflammation. Some examples of cartilage implants composed of BC are septum implants, ear implants, and intervertebral discs, among others [176]. Now a days, the use of bio-mimicking scaffolds has led to the exploration of $\mathrm{BC}$ as a potential scaffolding material. A previous study showed that $\mathrm{BC}$ did not induce the activation of pro- inflammatory cytokines during in vitro macrophage screening, but rather stimulated the biogenesis of collagen type II with chondrocytes seeded on BC membranes, indicating the suitability of BC as bio-mimicking scaffold [177]. Another more recent study showed the synthesis of modified bacterial cellulose (MBC) from metabolically engineered Gluconacetobacter xylinus with a high 

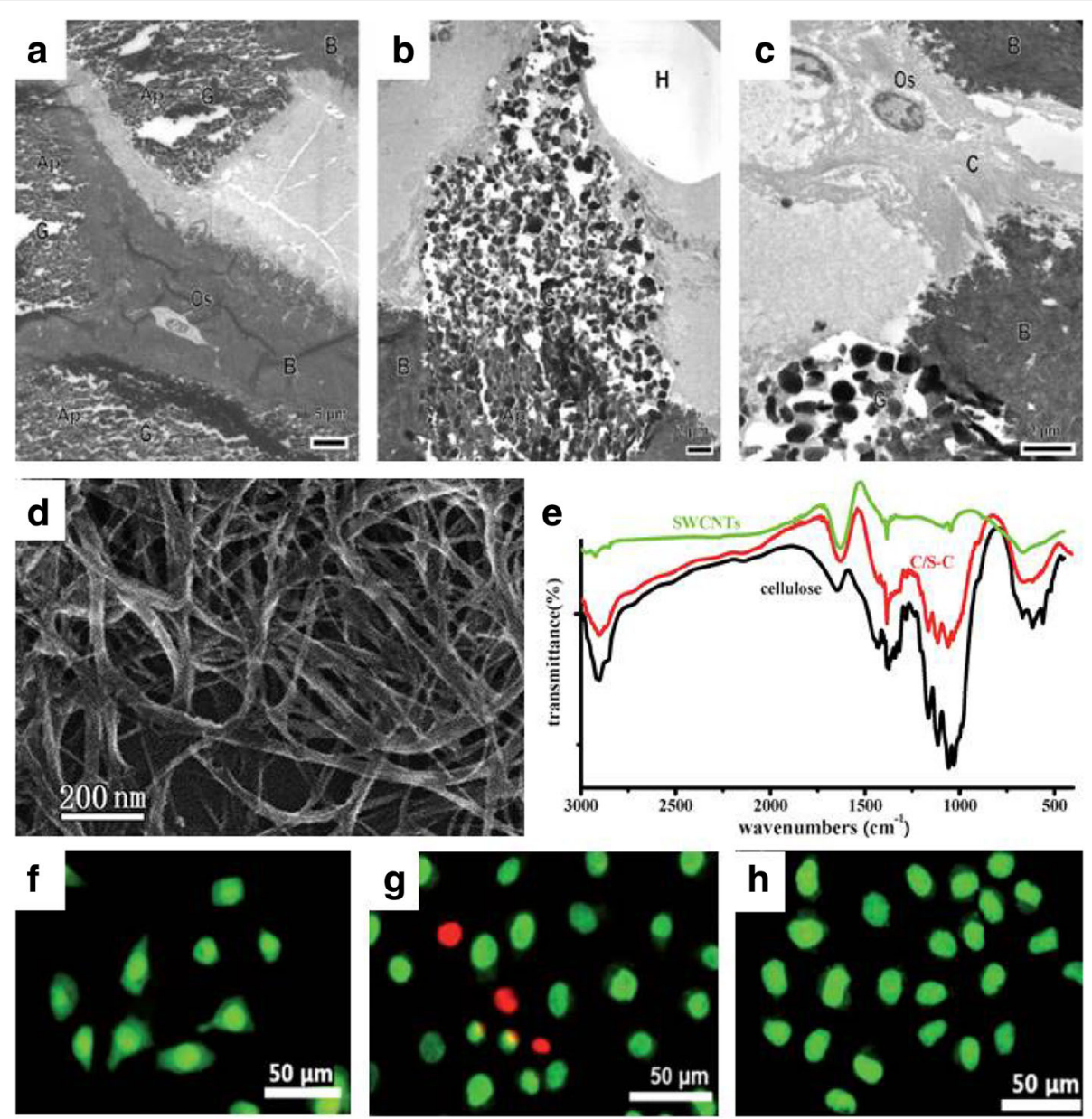

Fig. 9 TEM of IBS2-filled bone defects after 8 weeks (a-c). a The image clearly showed the mature bone tissue (B) containing the osteocytes (Os); b The vacuole containing the Si-HPMC polymer solution $(\mathrm{H})$ around the microporous BPC granules $(\mathrm{G})$ are visible; c The precipitation of the biological apatite (Ap) between the BPC crystals, collagen fibers (C), and the nucleus of osteoblastic cells can also be observed. [135]; $\mathbf{d}$ FE-SEM image of purified SWCNTs; e IR spectra of purified SWCNTs, cellulose and C/S-C; f-h. FM images of HeLa cells cultured for $24 \mathrm{~h}$ on the C/S-C (f), the SWCNTs (g), and a glass slide (h) [100, 138]. TEM: transmission electron microscopy; Si-HPMC: silated-hydroxypropylmethyl cellulose; BPC: biphasic calcium phosphate; FE-SEM: scanning electron microscopy; SWCNTs: single-walled carbon nanotubes; IR: infrared spectra; C/S-C: cellulose/SWCNTs complex

proliferation level of human mesenchymal stem cells (hMSCs) compared to native cellulose. This material was reported to be a novel in vivo degradable scaffold for chondrogenesis [178, 179].

\section{Blood vessel prototypes}

Artificial blood vessel-like structures composed of BC are almost $5-25 \mathrm{~cm}$ long, which are stable, mechanically strong and resistant to water, aqueous liquids, ions, and small particles, among others. Such vessel-like structure are often used as main platforms for neurotransmitters. Natural BNC has promising mechanical properties, including tear resistance and shaperetention properties, such that it is better suited for use as biological vessels [176].

\section{Wound dressing materials}

$\mathrm{BC}$ has been successfully used as wound dressing material since the 1980s. BC composite materials are used in medicine due to their biocompatible, sterile, porous, and flexible nature. The use of $\mathrm{BC}$ sheets allows for wounds to breathe, and prevent the formation of scabs and scars. On the other hand, the use of $\mathrm{BC}$ in dressing materials also reduces the amount of pain, protects the skin from infections, and reduces the loss of body fluids. As such, BC composite materials are an ideal candidate for the treatment of wounds and burns [180]. Some examples of commercially available $\mathrm{BC}$ composite gels are listed in Table 5 . A novel type of BC-based wound dressing, which is impregnated with superoxide dismutase and poviargol, 
Table 4 Uses of plant cellulose (PC), microbial cellulose (MC) and bacterial cellulose (BC) composite hydrogels in tissue engineering

\begin{tabular}{|c|c|c|c|}
\hline $\begin{array}{l}\text { Sl. } \\
\text { No. }\end{array}$ & Hydrogel composite & Applications & References \\
\hline 1 & Plant cellulose (PC) purified & Tissue engineering and regenerative medicine & [145]; Liu et al., 2014 [146] \\
\hline 2 & Algal cellulose (AC) & Bone tissue and cartilage engineering & [147] \\
\hline 3 & Bacterial cellulose (BC) purified & $\begin{array}{l}\text { Bone tissue engineering, cornea treatment, heart and vascular muscle } \\
\text { regeneration }\end{array}$ & [148] \\
\hline 4 & Carboxymethyl cellulose (CMC) & Drug loading and controlled release of drugs, nucleus pulposus & [149]; [148] \\
\hline 5 & Polyvinylpyrrolidone (PVP) & Soft-tissue replacement wound management & [149] \\
\hline 6 & Gelatin & Wound dressing, tissue regeneration & [80]; [150], [151] \\
\hline 7 & Starch & Reinforcement agent for bionanocomposites & [152] \\
\hline 8 & Alginate, sodium alginate & High strength hydrogel preparation & [153] \\
\hline 9 & Acrylic acid & Burn wound healing & [154] \\
\hline 10 & Graphene oxide (GO) & Biomedicine & [155] \\
\hline 11 & Vaccarin & Cell growth carrier wound dressing & {$[156]$} \\
\hline 12 & Hyaluronic acid (HA) & Wound dressing, tissue engineering & [157] \\
\hline 13 & Chondroitin sulfate (CS) & Dental material scaffold & Opera et al., 102 \\
\hline 14 & Calcium phosphate (CP) & Bone substitute & [158] \\
\hline 15 & $\begin{array}{l}\mathrm{Ca}^{2+} \text { activated cellulose, cellulose/ } \\
\text { lactide }\end{array}$ & Bone tissue engineering & [148] \\
\hline 16 & $\begin{array}{l}\text { 2-hydroxyethyl methacrylate } \\
\text { (PHEMA) }\end{array}$ & Contact lenses and optic component for biosensors & [159] \\
\hline 17 & Polyacrylamide & Cartilage replacement & [160] \& [161] \\
\hline 18 & Gellan gum & High strength hydrogel for synthetic connective tissue & [153] \\
\hline 19 & L-carrageenan & High strength hydrogel for synthetic connective tissue & [153] \\
\hline 20 & Hydroxyapatite & Bone scaffold substitute, bone tissue engineering & $\begin{array}{l}{[162] ;[163] ;[164] ;[165] ;} \\
{[166]}\end{array}$ \\
\hline 21 & Nanohydroxyapatite & Bone tissue engineering & \\
\hline 22 & Polyvinyl alcohol (PVA) & Cardiovascular soft tissue replacement, artificial cornea biomaterials & $\begin{array}{l}([167] ;[168]) ;[169] ;([170] ; \\
[171])\end{array}$ \\
\hline 23 & $\begin{array}{l}\text { Polylacitide and glycidyl } \\
\text { methacrylate }\end{array}$ & Skin repair material & {$[172]$} \\
\hline 24 & Collagen & Wound dressing for skin regeneration & [173]; [148] \\
\hline 20 & Silver & Antimicrobial wound dressing & [174]; [175] \\
\hline
\end{tabular}

was found to stimulate the healing of thermal skin burns resulting from acute radiation disease [183]. Surprisingly, BC/collagen type I composite was found to promote the reduction of protease, interleukins, and ROS activity in an in vitro culture study [184].

\section{Surgical implants}

$\mathrm{BCs}$ and BNCs can be used in the form of tracheotomy tubes for reconstructive surgery, such as for artificial heart valves, and as blood vessels in the form of nanotubes or neurotubes for the regeneration of coronary blood vessel

Table 5 Commercially available hydrogel wound dressing contains cellulose or its sodium salt. Most dressings are available in two forms, either as sheets or as amorphous gels. Products containing silver ions show antimicrobial property

\begin{tabular}{ll}
\hline The hydrogel wound dressing (producer) & Composition \\
\hline IntraSite $^{T M}$ Gel (Smith and Nephew) & Carboxymethycellulose sodium (CMCNa), propylene glycol and water \\
GranuGel $^{T M}$ (ConvaTec) & Carboxymethycellulose sodium (CMCNa), Propylene glycol, pectin and water \\
Purilon Gel & Carboxymethycellulose (CMC), calcium alginate and water \\
Aquacel Ag & [181], [182] \\
Silvercel ${ }^{T M}$ (Johnson and Johnson) & Carboxymethycellulose sodium (CMCNa) and silver ions (1.2\%) \\
\hline
\end{tabular}


and nerves. Previous studies have found new epithelial cell layers to form over these artificial $\mathrm{BC}$ tubes, demonstrating the successful application of $\mathrm{BC}$ in tissue implantation [185]. The use of PVA/BC nanocomposites for the replacement of cardiovascular tissues has also been reported, since these would mimic the role of natural collagen and elastin (a connective tissue protein that helps skin to return to its original position $[167,168]$

\section{Potential drug delivery material}

Transdermal systems can act as an entry gate for BCs into the domain of drug delivery systems [186]. BC dry films have been obtained after the successful immersion of these in benzalkonium chloride (an antimicrobial agent). Their subsequent drug loading capacity was found to be $0.116 \mathrm{mg} / \mathrm{cm}^{2}$ (per unit surface area), and the effect of drug was found to last for at least $24 \mathrm{~h}$ against Staphylococcus aureus and Bacillus subtilis applied to the wounded area [187]. Silver nanoparticle-coated BC fibers showed 99.99\% antimicrobial activity against Escherichia coli and S. aureus [164]. Despite these promising results, the application of BC hydrogels involves certain clinical and pharmacological limitations. However, despite these limitations, the complex nanofibrillar structure of BC represents a suitable macromolecular support for the inclusion of drugs, i.e. for use as a drug carrier [188].

\section{Artificial grafting of cornea}

Corneal disease is a serious health problem that can lead to partial or complete blindness. An estimated 10 million people have lost their eyesight due to corneal infection or similar diseases. With this in mind, researchers around the world have developed biomaterials for the treatment of defective corneas. The properties of bacterial cellulose, including its nanoporous structure, and excellent mechanical properties, make it an ideal candidate for use as an artificial cornea to help maintain the intraocular pressure of the eye and re-establish ocular pellucidity. The BC/polyvinyl alcohol (BC/PVA) hydrogel has a water content and light transmittance comparable to that of natural cornea and was successfully synthesized and described by Wang et al. for this end.

\section{Dental implants}

BC composite hydrogels were prepared from Acetobacter hansenii by [189] for used in dental root canal treatment (RCT) due to intracanal asepsis. Dental RCT is required when dental caries progress to infection of the dental pulp. From a materials point of view, BC has superior properties compared to plant cellulose (paper points) for the use in dental RCT. Moreover, research has demonstrated the tissue regeneration of periodontal cells after the application of BC hydrogels [190, 191].

\section{Other applications}

Biomimetic scaffolds are of great interest to tissue engineering as they supports essential cell functions. BNC scaffolds in combination with soluble collagen-I stimulate estrogenic differentiation of mesenchymal stem cells (MSCs) [Vielreicher et al., 2018]. The use of cell-derived ECM collagen-I holds good potential, particularly for the tissue engineering of mechanically-challenged tissues. An optimized method for the purification of nano- fibrillated cellulose (NFC) and hydrogel production from wood cellulose was described for the development of a wound dressing material [192]. Inflammation, autolytic debridement, granulated tissue formation, and re- epithelialization are the processes that generally occur during wound healing. Wound dressings are designed to promote healing while protecting the wounds from infection. This is particularly important in cases of chronic wounds (e.g., ulcers), which fail to heal properly. Since a moist environment encourages rapid healing, hydrogels are optimal candidates for the development of wound dressings, either as sheets or in an amorphous form [193]. Various types of hydrogel dressings have been patented so far and are currently commercially available (Table 5), based on synthetic or natural polymers, or a combination of these. Among the most recent patents, it is worth citing those describing in situ forming gels (e.g., based on sprayable formulations [194] and on coalescing nanoparticles [195]), and those exploring radiation crosslinking as a stabilization technique, which allows to obtain sterile and cross-linked hydrogel films in a single-step process [196, 197].

Scaffold attempts to mimic natural ECMs. The most common method of tissue engineering includes the use of biodegradable scaffolds to support the growth and development of cells into tissues or by injecting the isolated single cell suspensions [5]. Cellulose-based scaffolding materials are widely used to regenerate various tissues, such as bone, cartilage, heart, blood vessel, nerve, and liver, among others. However, the design of scaffolds often involves issues related to the need requirement for adequate cell-cell adhesion, cell-cell communication, and cell-ECM communication, which are crucial features of tissue functioning [198]. To overcome these problems, biodegradable scaffolds have been developed. Since, natural polymers are biocompatible, their use allows us to avoid stimulating chronic inflammation or immunological reactions or toxicity. Therefore, hydrogels are used extensively in tissue engineering due to their high swelling properties and their biocompatibility. As a result, they can be incorporated the cells of soft tissues and bioactive molecules via gelling process [199].

\section{Conclusion and future directions}

The current review clearly shows that based explicitly on cellulose biopolymers, hydrogels are a diverse class of 
materials that have widespread applications in the field of tissue engineering and regenerative medicine. In these areas, scaffolds played a significant role and have been developed to form temporary, artificial ECMs to support cell attachment and three-dimensional (3D) tissue formation. Due to their high mechanical strength and thermostability, bacterial cellulose derivatives are widely used for wound dressing and healing, providing a novel method for the treatment of epidermal burns. Most interestingly, the work of researchers across the globe in the fields of cellulose hydrogel development and characterization seem to indicate that hydrogels based on cellulosic biomaterials could be potential candidates for applications in the field of tissue engineering. However, the research outcomes appear somewhat different from the promising predictions. For example, while using hydrogels in bioengineering applications, researchers have encountered a number of problems. These include difficulties in the handling, maintenance, storage of hydrogels, for example, for hydrogels designed using bioprinters, which are not as much mechanically strong as was theoretically determined. During in vitro experiments it was more difficult to sterilize scaffolding structures than, for example, the cell culture media. Sterilizing by means of autoclaving can cause the functional properties of cellulose-based hydrogels to change. However, their sterilization is necessary since the use of hydrogels without proper sterilization could be a large source of contamination during in vivo and in vitro experiments in laboratory. Researchers have also often encountered difficulties while loading hydrogels with drugs or cells for controlled drug delivery. Further research into hydrogels will be required for the development of new methods and protocols in order to overcome these limitations. Despite these issues, the use of $\mathrm{BC}$ hydrogels compared to plant-derived or manmade hydrogels is currently on the rise due to the cost-effective production of $\mathrm{BC}$ hydrogels using stirred-tank or static bioreactors. However, more needs to be done to improve plant-derived cellulosic gel production (PC hydrogels). The use of cellulose-based hydrogels in tissue engineering has both advantages and disadvantages, the latter of which will need to be resolved before cellulosic hydrogels can be more widely applied.

Researchers are also working to improve our understanding of the mechanism behind the molecular interaction involved in cellulose ECM materials so that, in the future, materials that mimic natural ECMs in terms of their composition, structural characteristics, and mechanical properties can be developed. The proper development of 3D scaffolding materials could be used to replace conventional tissue engineering techniques to a great extent. Cellulose- based hydrogels have important applications in tissue engineering due to their high biocompatibility and environment- friendly properties.
Cellulose-based hydrogels have been recently modified using a nontoxic cross-linking agent or cross-linking treatments, to improve the yield of both the final product and the manufacturing processes. However, further research is needed to develop more advanced cellulose-based hydrogels for use in healthcare and medicine.

\section{Additional file}

Additional file 1: Table S1. a-Cellulose content of some plant products [197-204]. Figure S1: Source of some naturally occurring cellulose. a. hard wood (beech tree); b. cotton tree; c. bamboo; d. Gluconacetobacter xylinum; e. ascidians. Figure S2. Hydrogen bonding pattern in cellulose molecule. The hydrogen bonding within or between cellulose molecules represents its crystalline nature while studying through X-ray diffraction or NMR technique. Figure S3. Microphotograph showing variation in morphology of different fibers. a. twisted cotton fibers; b. tracheids of spruce wood; c. straight fibers of ramie. Copyright permission from [205]; simplified model of plant cell wall. $d$. structure of $S_{1}-S_{3}$ layer; e-f. Cellulose assembly with pectin, hemicellulose, and lignin. Copyright permission from ([49]; [206-208]). (DOCX $312 \mathrm{~kb}$ )

\section{Abbreviations}

3D: Three-dimensional; AMIMCl: 1-allyl-3-methylimidazolium chloride; BC: Bacterial cellulose; BCP: Biphasic calcium phosphate; BMIMCl: 1-butyl-3methylimidazolium chloride; BNC: Bacterial nanocellulose; CdHAP: Calciumdeficient hydroxyapatite; CMC: Carboxymethyl cellulose;

CMCNa: Carboxymethylcellulose sodium salt; DMA: Dynamic mechanical analysis; DMAc: Dimethylacetamide; DMSO/TBAF: Dimethysulfoxide/ tertrabutylaluminium fluoride trihydrate; DP: Dope characteristics; EBs: Embryonic bodies; ECM: Extracellular matrix; GAGs: Glycosaminglycans; HEC: Hydroxyethylcellulose; hESCs: Human embryonic stem cells; HPC: Hydroxypropyl cellulose; HPMC: Hydroxypropylmethyl cellulose; ILS: Ionic liquids; IR: Infrared; LiCl: Lithium chloride; MBC: Modified bacterial cellulose; MC: Methyl cellulose; MSCs: Mesenchymal stem cells; $\mathrm{NaOH}$ : Sodium hydroxide; NFC: Nano-fibrillated cellulose; NMMO: Nmethylmorpholine-N-oxide; NMR: Nuclear magnetic resonance; PC: Plant cellulose; PM: Patterned macroporous; ROS: Reactive oxygen species; SA: Sodium alginate; SEM: Scanning electron microscopy; Si-HPMC: Silatedhydroxypropylmethyl cellulose; SWCNTs: Single-walled carbon nanotubes; TGA: Thermo-gravimetric analysis; UV: Ultra-violet; WXRD: Wide-angle X-ray diffraction

\section{Acknowledgements}

The authors would like to thank Prof. Lim for his continuous support to write the manuscript.

\section{Funding}

This research was supported by 'Co-operative Research Program for Agriculture Science and Technology Development (No. PJ012854012017)', Rural Development Administration, Republic of Korea and 'Basic Science Research Program' through the 'National Research Foundation of Korea' funded by the Ministry of Education (No. 2018R1A6A1A03025582) and the 'National Research Foundation of Korea' (NRF-2016R1D1 A3B03932921).

\section{Availability of data and materials}

Not applicable.

\section{Authors' contributions}

SDD wrote the manuscript. DKP and KTL reviewed the manuscript, edited, and provided feedback. KTL read and approved the final manuscript.

Ethics approval and consent to participate Not applicable.

Consent for publication

Not applicable. 


\section{Competing interests}

The authors declare no competing interests.

\section{Publisher's Note}

Springer Nature remains neutral with regard to jurisdictional claims in published maps and institutional affiliations.

\section{Author details}

Biorobotics Laboratory, Department of Biosystems Engineering, Kangwon National University, Chuncheon, Republic of Korea. ${ }^{2}$ The Institute of Forest Science, Kangwon National University, Chuncheon 24341, Republic of Korea.

\section{Received: 24 February 2019 Accepted: 10 May 2019}

\section{Published online: 20 June 2019}

\section{References}

1. Silva AKA, Richard C, Bessodes M, Scherman D, Merten OW. Growth factor delivery approaches in hydrogels. Biomacromolecules. 2009. https://doi.org/ $10.1021 / \mathrm{bm} 801103 \mathrm{c}$

2. Peppas NA, Bures P, Leobandung W, Ichikawa H. Hydrogels in pharmaceutical formulations. Eur J Pharm Biopharm. 2000. https://doi.org/ 10.1016/50939-6411(00)00090-4

3. Peppas NA, Mikos AG. Preparation methods and structure of hydrogels. In: Peppas NA, editor. Hydrogels in medicine and pharmacy. Florida: CRC Press; 1986. p. 1-27.

4. Stauffer SR, Peppas NA. Poly (vinyl alcohol) hydrogels prepared by freezingthawing cyclic processing. Polymer. 1992. https://doi.org/10.1016/00323861(92)90385-A.

5. Drury JL, Mooney DJ. Hydrogels for tissue engineering: scaffold design variables and applications. Biomaterials. 2003. https://doi.org/10.1016/j. biomaterials.2010.02.044

6. Bajpai AK, Shukla SK, Bhanu S, Kankane S. Responsive polymers in controlled drug delivery. Prog Polym Sci. 2008. https://doi.org/10.1016/j.progpolymsci. 2008.07.005.

7. Vinogradov SV, Bronch TK, Kabanov AV. Nanosized cationic hydrogels for drug delivery preparation, properties and interactions with cells. Adv Drug Deliv Rev. 2002. https://doi.org/10.1016/50169-409X(01)00245-9.

8. Ostrovidova GU, Makeev AV, Shamtsian MM. Polyfunctional film coatings for medical use. J Mater Sci Eng. 2003. https://doi.org/10.1016/S09284931(03)00031-6.

9. Ratner, BD, Hoffman AS. Process of radiation grafting hydrogels onto organic polymeric substrates. 1976; US Patent US3939049A.

10. Lee YJ, Braun PV. Tunable inverse opal hydrogel pH sensors. Adv Mater. 2003. https://doi.org/10.1002/adma.200304588.

11. Sorber J, Steiner G, Schulz V, Guenther M, Gerlach G, Salzer R, et al. Hydrogel-based piezoresistive pH sensors: Investigations using FT-IR attenuated total reflection spectroscopic imaging. Anal Chem. 2008. https:// doi.org/10.1021/ac702598n

12. Khan F, Tare R, Richard O, Oreffo R, Bradley M. Versatile biocompatible polymer hydrogels: scaffolds for cell growth. Angewandate Chemie Int Edn. 2009. https://doi.org/10.1002/anie.200804096.

13. Lee KY, Mooney DJ. Hydrogel for tissue engineering. Chem Rev. 2001. https://doi.org/10.1021/cr000108x.

14. Katsoulos C, Karageorgiadis L, Vasileiou N, Mousafeiropoulos T, Asimellis G. Customized hydrogel contact lenses for keratoconus incorporating correction for vertical coma aberration. Ophthalmic Physiol Opt. 2009. https://doi.org/10.1111/j.1475-1313.2009.00645.x.

15. Yasuda H. Biocompatibility of nanofilm-encapsulated silicone and siliconehydrogel contact lenses. Macromol Biosci. 2006. https://doi.org/10.1002/ mabi.200500153.

16. Wu D, Wang $T$, Lu B, Xu X, Cheng $S$, Jiang X, et al. Fabrication of supramolecular hydrogels for drug delivery and stem cell encapsulation. Langmuir. 2008. https://doi.org/10.1021/la8006876.

17. Nagahama K, Ouchi T, Ohya Y. Temperature-induced hydrogels through self-assembly of cholesterol-substituted star PEG-b-PLLA copolymers: an injectable scaffold for tissue engineering. Adv Funct Mat. 2008. https://doi. org/10.1002/adfm.200700587.

18. Zhu J. Bioactive modification of poly (ethylene glycol) hydrogels for tissue engineering. Biomaterials. 2010. https://doi.org/10.1016/j.biomaterials.2010, 02.044 .
19. Martens PJ, Bryant SJ, Anseth KS. Tailoring the degradation of hydrogels formed from multivinyl poly (ethylene glycol) and poly (vinyl alcohol) macromers for cartilage tissue engineering. Biomacromolecules. 2003. https://doi.org/10.1021/bm025666v.

20. Ferruti P, Bianchi S, Ranucci E, Chiellini F, Piras AM. Novel agmatinecontaining poly (amidoamine) hydrogel as scaffolds for tissue engineering. Biomacromolecules. 2005. https://doi.org/10.1021/bm050210+.

21. Nayak S, Lee H, Chmielewski J, Lyon LA. Folate-mediated cell targeting and cytotoxicity using thermoresponsive microgels. J Am Chem Soc. 2004. https://doi.org/10.1021/ja0474143.

22. Gao D, Xu H, Philbert MA, Kopelman R. Ultrafine hydrogel nanoparticles: synthetic approach and therapeutic application in living cells. Angewandate Chemie Int Edn. 2007. https://doi.org/10.1002/ange.200603927.

23. Tomatsu I, Hashidzume A, Harada A. Contrast viscosity changes upon photoirradiation for mixtures of poly(acrylic acid)-based a-cyclodextrin and azobenzene polymers. J Am Chem Soc. 2006. https://doi.org/10.1021/ ja058345a.

24. Kim DG, Seo SW, Cho BK, Lohumi S, Hong SJ, Lee WH. Review of current approaches for implementing metabolic reconstruction. J Biosyst Eng. 2018. https://doi.org/10.5307/JBE.2018.43.1.045.

25. Hoffman AS. Hydrogels for biomedical applications. Adv Drug Deliv Rev. 2002;43:3-12.

26. Temenoff JS, Mikos AG. Injectable biodegradable materials for orthopedic tissue engineering. Biomaterials. 2002. https://doi.org/10.1016/501429612(00)00108-3.

27. Buxton AN, Zhu J, Marchant RE, West JL, Yoo JU, Johnstone B. Design and characterization of poly(ethylene glycol) photopolymerizable semiinterpenetrating networks for chondrogenesis of human mesenchymal stem cells. Tissue Eng. 2007. https://doi.org/10.1089/ten.2007.0075.

28. Hahn MS, McHale MK, Wang E, Schmedlen RH, West JL. Physiologic pulsatile flow bioreactor conditioning of poly (ethylene glycol)-based tissue engineered vascular grafts. Ann Biomed Eng. 2007. https://doi.org/10.1007/ s10439-006-9099-3.

29. O'Sullivan AC. Cellulose: the structure slowly unravels. Cellulose. 1997:4:173207.

30. Eichhorn SJ, Young RJ, Davies GR. Modeling crystal and molecular deformation in regenerated cellulose fibers. Biomacromolecules. 2005. https://doi.org/10.1021/bm049409x.

31. Schurz J. "Trend in polymer science" a bright future for cellulose. Prog Polym Sci. 1999;24:481.

32. Hon DNS. Cellulose and its derivatives: structures, reactions, and medical uses. In: Dumitriu S, editor. Polysaccharides in medical applications. New York: Marcel Dekker; 1996. p. 87-105.

33. Eichhorn SJ, Baillie CA, Zafeiropoulos N, Mwaikambo LY, Ansell MP, Dufresne A, et al. Current international research into cellulosic fibers and composites. J Mater Sci. 2001. https://doi.org/10.1023/A:1017512029696.

34. Vandamme EJ, De Baets S, Vanbaelen A. Improved production of bacterial cellulose and its application potential. Polym Degrad Stab. 1998;59:93-9.

35. Jonas R, Farah LF. Production and application of microbial cellulose. Polym Degrad Stab. 1998. https://doi.org/10.1016/S0141-3910(97)00197-3.

36. Dutta SD, Tarafder M, Islam R, Datta BS. Characterization of cellulolytic enzymes of fusarium soli isolates. Biocatal Agri Biotechnol. 2018. https://doi. org/10.1016/j.bcab.2018.03.011.

37. Brown RM Jr, Saxena IM. Cellulose biosynthesis: a model for understanding the assembly of biopolymers. Plant Physiol Biochem. 2000. https://doi.org/ 10.1016/50981-9428(00)00168-6.

38. Rao VSR, Sundararajan PR, Ramakrishnan C, Ramachandran GN. Conformational studies of amylose. In: Ramachandran GN, editor. Conformation of biopolymers (Vol II). London: Academic; 1967. p. 721-37.

39. Krassig HA. Cellulose: structure, accessibility and reactivity. Gordon and Breach Science: Yverdon; 1993.

40. Sorieul M, Dickson A, Hill SJ, Pearson H. Plant fibre: molecular structure and biomechanical properties, of a complex living material, influencing its deconstruction towards a biobased composite. Materials. 2016. https://doi. org/10.3390/ma9080618.

41. Seo YR, Kim JW, Hoon S, Kim J, Chung JH, Lim KT. Cellulose-based nanocrystals: sources and applications via agricultural by-products. J Biosyst Eng. 2018. https://doi.org/10.5307/JBE.2018.43.1.059.

42. Kondo $T$. The relationship between intramolecular hydrogen bonds and certain physical properties of regioselectively substituted cellulose 
derivatives. J Polym Sci A Part B: Polym Phys. 1998. https://doi.org/10.1002/ (SICI) 1099-0488(199703)35:4<717::AID-POLB18>3.0.CO;2-J.

43. Sarko A, Muggli R. Packing analysis of carbohydrates and polysaccharides. III. Valonia cellulose and cellulose II. Macromolecules. 1974. https://doi.org/10. 1021/ma60040a016.

44. Atalla RH, VanderHart DL. Native cellulose: a composite of two distinct crystalline forms. Science. 1984. https://doi.org/10.1126/science.223.4633.283.

45. Marchessault RH, Sarko A. X-ray structureof polysaccharides. In: Wolfrom ML, editor. Advanced Carbohydrate Chemistry. New York: Academic Press; 1967. p. 421-83.

46. Walton AG, Blackwell J. Biopolymers Vol. 22. New York: Academic; 1973. p. 468.

47. VanderHart DL, Atalla RH. Studies of microstructure in native celluloses using solid state C-13 NMR. Macromolecules. 1984. https://doi.org/10.1021/ ma00138a009.

48. Sugiyama J, Persson J, Chanzy H. Combined IR and electron diffraction study of the polymorphism of native cellulose. Macromolecules. 1991. https://doi.org/10.1021/ma00009a050.

49. Marrinan M, Mann J. Infrared spectra of the crystalline modifications of cellulose. J Polym Sci. 1956. https://doi.org/10.1002/pol.1956.120219812.

50. Hayashi J, Sufoka A, Ohkita J, Watanabe S. The conformation of existence of cellulose III, IIII, IV and IV ${ }_{\text {II }}$ by X-ray method. J Polym Sci Polym Lett Edn. 1975. https://doi.org/10.1002/pol.1975.130130104.

51. Nyburg SC. Fibrous macromolecular substances. In: Fieser LF, Fieser M, editors. X-ray analysis of organic structures. New York: Academic; 1961. p. 302-14.

52. Kuga S, Takagi S, Brown RM Jr. Native folded-chain cellulose II. Polymer. 1993. https://doi.org/10.1016/0032-3861(93)90404-X.

53. Hess $\mathrm{K}$, Kissig $\mathrm{H}$. To note the high-temperature modification of cellulose. Magazine Phys Chem. 1941. https://doi.org/10.1515/zpch-1941-4922.

54. Gardiner ES, Sarko A. Packing analysis of carbohydrates and polysaccharides. 16. The crystal structures of celluloses IV $V_{\perp}$ and IVI. Can J Chemistry. 1985. https://doi.org/10.1139/v85-027.

55. Gardner KH, Blackwell J. Structure of native cellulose. Biopolymers. 1974. https://doi.org/10.1002/bip.1974.360131005.

56. Klemm D, Heublein B, Fink HP, Bohn A. Cellulose: fascinating biopolyme and sustainable raw material. Angew Chem Int Ed. 2005. https://doi.org/10. 1002/anie.200460587.

57. Shi Z, Zhang Y, Phillips GO, Yang G. Utilization of bacterial cellulose in food. Food Hydrocol. 2014. https://doi.org/10.1016/j.foodhyd.2013.07.012.

58. loelovich M, Leykin A. Cellulose as a nanostructured polymer: a short review. Bioresources. 2008;3:1403-18.

59. Rytioja J, Hilden K, Yuzon J, Hatakka A, de Vries RP, Makela MR. Plantpolysaccharide-degrading enzymes from basidiomycetes. Microbiol Mol Biol Rev. 2014. https://doi.org/10.1128/MMBR.00035-14.

60. Plomion C, Leprovost G, Stokes A. Wood formation in trees. Plant physiol. 2001; https://doi.org/10.1104/pp.010816

61. Schubert S, Schlufter K, Heinze T. Configurations, structures, and morphologies of cellulose. In: Popa V, editor. Polysaccharides in medicinal and pharmaceutical applications. Shrewsbury: iSmithers; 2011. p. 1-55

62. Klemm D, Schumann D, Udhardt U, Marsch S. Bacterial synthesized cellulose - artificial blood vessels for microsurgery. Prog Polym Sci. 2001. https://doi. org/10.1016/S0079-6700(01)00021-1.

63. Kongruang S. Bacterial cellulose production by Acetobacter xylinum strain from agricultural waste products. Appl Biochem Biotechnol. 2008. https:// doi.org/10.1007/978-1-60327-526-2_70.

64. Scott JE. Extracellular matrix, supramolecular organization and shape. J Anat. 1995;187:259-69.

65. Rhodes JM, Simons $M$. The extracellular matrix and blood vessel formation: not just a scaffold. J Cell Mol Med. 2007. https://doi.org/10.1111/j.1582-4934. 2007.00031.x.

66. Cukierman E, Pankov R, Yamada KM. Cell interactions with threedimensional matrices. Curr Opin Cell Biol. 2002. https://doi.org/10.1016/ S0955-0674(02)00364-2.

67. Shastri VP, Forget A. Development of the next generation of synthetic extracellular matrices for 3D cell culture. Lab \& More. 2014; http://www.int laborundmore.com/archive/543411/ Development-of-the-next-generationof-synthetic-extracellular-matrices-for-3D-cell-culture.html.

68. Das N. Biodegradable hydrogels for controlled drug delivery. In: Mondal IM, editions. Cellulose-based superabsorbent hydrogels. Springer Nature. 2018. p.1-41.
69. Prashant PK, Vivek BR, Deepashree ND, Pranav PP. Hydrogels as a drug delivery system and applications: a review. Int J Pharm Pharm Sci. 2012:4:1-7.

70. Das N, Bera T, Mukherjee A. Biomaterial hydrogels for different biomedical applications. Int J Pharm Bio Sci. 2012;3:586-95.

71. Grassi M, Sandolo C, Perin D, Coviello T, Lapasin R, Grassi G. Structural characterization of calcium alginate matrices by means of mechanical and release tests. Molecules. 2009. https://doi.org/10.3390/molecules14083003.

72. De SK, Aluru N, Johnson B, Crone W, Beebe DJ, Moore J. Equilibrium swelling and kinetics of pH-responsive hydrogels: models, experiments, and simulations. J Microelectromech Syst. 2002. https://doi.org/10.1109/JMEMS. 2002.803281.

73. Bryant SJ, Nuttelman CR, Anseth KS. Cytocompatibility of UV and visible light photoinitiating systems on cultured $\mathrm{NIH} / 3 \mathrm{~T} 3$ fibroblasts in vitro. J Biomater Sci Polym Ed. 2000. https://doi.org/10.1163/156856200743805.

74. Akiyoshi K, Deguchi S, Moriguchi N, Yamaguchi S, Sunamoto J. Selfaggregates of hydrophobized polysaccharides in water: formation and characteristics of nanoparticles. Macromolecules. 1993. https://doi.org/10. 1021/ma00064a011

75. Morimoto N, Winnik FM, Akiyoshi K. Botryoidal assembly of cholesterylpullulan/ poly(nisopropylacrylamide) nanogels. Langmuir. 2007. https://doi. org/10.1021/la0616045.

76. Mohite BV, Koli SH, Patil SV. Bacterial cellulose-based hydrogels: Synthesis, Properties, and Applications. In: Mondal IH, editor. Cellulose-based superabsorbent hydrogels: Springer Nature; 2018. p. 1-22.

77. Fan M, Ma Y, Tan H, Jia Y, Zou S, Guo S, et al. Covalent and injectable chitosan-chondroitin sulfate hydrogels embedded with chitosan microspheres for drug delivery and tissue engineering. Mater Sci Eng C. 2007. https://doi.org/10.1016/j.msec.2016.09.068.

78. Singh B, Sharma V. Crosslinking of poly(vinylpyrrolidone)/acrylic acid with tragacanth gum for hydrogels formation for use in drug delivery applications. Carbohydr Polym. 2017. https://doi.org/10.1016/j.carbpol.2016.09.086.

79. Hamidi M, Azadi A, Rafiei P. Hydrogel nanoparticles in drug delivery. Adv Drug Deliv Rev. 2008;60:1638-49.

80. Păvăloiu RD, Stoica-Guzun A, Dobre T. Swelling studies of composite hydrogels based on bacterial cellulose and gelatin. UPB Sci Bull Ser B. 2015;77:53-62.

81. Mohite BV, Patil SV. A novel biomaterial: bacterial cellulose and its new era applications. Biotechnol Appl Biochem. 2014. https://doi.org/10.1002/bab.1148.

82. Ross P, Mayer R, Benziman M. Cellulose biosynthesis and function in bacteria. Microbiol Rev. 1991;55(1):35-58

83. Gromet-Elhanan Z, Hestrin S. Synthesis of cellulose by Acetobacter xylinum VI. Growth on citric acid-cycle intermediates. J Bacteriol. 1963;85:284-92.

84. Rajwade JM, Paknikar KM, Kumbhar JV. Applications of bacterial cellulose and its composites in biomedicine. Appl Microbiol Biotechnol. 2015. https:// doi.org/10.1007/s00253-015-6426-3.

85. Jung JY, Park JK, Chang HN. Bacterial cellulose production by Gluconacetobacter hansenii in an agitated culture without living noncellulose producing cells. Enzym Microb Technol. 2005. https://doi.org/10. 1016/j.enzmictec.2005.02.019.

86. Yoshino T, Asakura T, Toda K. Cellulose production by Acetobacter pasteurianus on silicone membrane. J Ferment Bioeng. 1996. https://doi.org/ 10.1016/0922-338X(96)83116-3.

87. Ishihara M, Yamanaka S. Modified bacterial cellulose. 2000. US Patent US6060289A.

88. Shoda M, Sugano Y. Recent advances in bacterial cellulose production. Biotechnol Bioprocess Eng. 2005. https://doi.org/10.1007/BF02931175.

89. Gatenholm P. Cellulose nanofibriller bioink for 3D bioprinting for cell culturing, tissue engineering and regenerative medicine applications. 2017. US Patent US20170368225A1.

90. Kim JY, Kim JN, Wee YJ, Park DH, Ryu HW. Bacterial cellulose production by Gluconacetobacter sp. PKY5 in a rotary biofilm contactor. Appl Biochem Biotechnol. 2007. https://doi.org/10.1007/s12010-007-9077-8.

91. Pita PCDC, Pinto FCM, Lira MMDM, Melo FDAD, Ferreira LM, Aguiar JLDA. Biocompatibility of the bacterial cellulose hydrogel in subcutaneous tissue of rabbits. Acta Cir Bras. 2015. https://doi.org/10.1590/S0102865020150040000009

92. Czaja W, Romanovicz D, Brown RM. Structural investigations of microbial cellulose produced in stationary and agitated culture. Cellulose. 2004. https://doi.org/10.1023/B:CELL.0000046412.11983.61.

93. Watanabe K, Tabuchi M, Morinaga Y, Yoshinaga F. Structural features and properties of bacterial cellulose produced in agitated culture. Cellulose. 1998. https://doi.org/10.1023/A:1009272904582. 
94. Kim DY, Nishiyama Y, Kuga S. Surface acetylation of bacterial cellulose. Cellulose. 2002. https://doi.org/10.1023/A:1021140726936.

95. Okiyama A, Motoki M, Yamanaka S. Bacterial cellulose IV. Application to processed foods. Food Hydrocoll. 1993. https://doi.org/10.1016/S0268005X(09)80074-X.

96. Chang C, Zhang L. Cellulose-based hydrogels: present status and application prospects. Carbohydrate Polym. 2011. https://doi.org/10.1016/j. carbpol.2010.12.023.

97. Zhang Y, Shao H, Wu C, Hu X. Formation and characterization of cellulose membranes from N-methylmorpholine-N-oxide solution. Macromol Biosci. 2001. https:/doi.org/10.1002/1616-5195(20010601)1:4<141::AID-MABI141>3.0.CO;2-J.

98. Saito $H$, Sakurai A, Sakakibara M, Saga H. Preperation and properties of transparent cellulose hydrogels. J Appl Polym Sci. 2003. https://doi.org/10. 1002/app.13015.

99. De Oliveira WD, Glasser WG. Hydrogels form polysacchardies I Cellulose beads for chromatographic support. J Appl Polym Sci. 1996. https://doi.org/ 10.1002/(SICI) 1097-4628(19960404)60:1<63:.AID-APP8>3.0.CO;2-T.

100. Wang Z, Lu S, Matsumoto Y, Kuga S. Cellulose gel and aerosol from LiCl/ DMSO solution. Cellulose. 2012. https://doi.org/10.1007/s10570-012-9651-2.

101. Li L, Lin Z, Yang X, Wan ZZ, Cui SX. A novel cellulose hydrogel prepared from its ionic liquid solution. Chin Sci Bull. 2009a. https://doi.org/10.1007/ s11434-009-0207-2.

102. Li L, Meng L, Zhang X, Fu C, Lu Q. The ionic liquid-associated synthesis of a cellulose/SWCNT complex and its remarkable biocompatibility. J Mater Chem. 2009b. https://doi.org/10.1039/b823322e.

103. Cai J, Zhang L. Rapid dissolution of cellulose in $\mathrm{LiOH} /$ urea and $\mathrm{NaOH} / \mathrm{urea}$ aqueous solution. Macrol Biosci. 2005. https://doi.org/10.1002/mabi. 200400222.

104. Liang SM, Zhang L, Li Y, Xu J. Fabrication and properties of cellulose hydrated membrane with unique structure. Macromol Chem Phys. 2007. https://doi.org/10.1002/macp.200600579.

105. Bao Y, Ma J, Li N. Synthesis and swelling behaviors of sodium carboxymethyl cellulose-g-poly (AA-co-AM-co-AMPS)/MMT superabsorbent hydrogel. Carbohydr Polym. 2011. https://doi.org/10.1016/j.carbpol.2010.10.061.

106. Bao Y, Ma J, Sun Y. Swelling behaviors of organic/inorganic composites based on various cellulose derivatives and inorganic particles. Carbohydr Polym. 2012. https://doi.org/10.1016/j.carbpol.2012.01.003.

107. Feddersen RL, Thorp SN. Chapter 20-sodium carboxymethycellulose. In: Whistler RL, Bemiller JN, editors. Industrial gums: polysaccharides and their derivatives. 3rd ed. Elsevier: Academic; 1993. https://doi.org/10.1016/B978-008-092654-4.50024-3

108. Bortolin A, Aouadas FA, Mattoso LHC, Ribeiro CR. Nanocomposite PAAm/ methyl cellulose/montmorillonite hydrogel: evidence of synergistic effects for the slow release of fertilizers. J Agric Food Chem. 2013. https://doi.org/ 10.1021/jf401273n

109. Duarte ARC, Gordillo MD, Cardoso MM, Simplicio AL, Durate CMM. Perperation of ethyl cellulose/methyl cellulose blends by supercritical antisolvent precipitation. Int J Pharm. 2006. https://doi.org/10.1016/j.jpharm. 2005.12.010

110. Brown W, Henely D. Studies on cellulose derivatives. Part III. Unperturbed dimensions of hydroxyethyl cellulose and other derivatives in aqueous solvents. Macromol Chem Phys. 1964. https://doi.org/10.1002/macp.1964.020750115.

111. Frey MW. Electrospinning cellulose and cellulose derivatives. Polym Rev. 2008. https://doi.org/10.1080/15583720802022281.

112. Oliveria VA, Veloso TC, Leao VA, dos Santos CG, Botaro VR. Hydrogels of cellulose acetate crosslinked with pyromellitic dianhydride-part I: synthesis and swelling kinetics. Quim Nova. 2013. https://doi.org/10.1590/S010040422013000100019.

113. Edgar KJ, Buchanan CM, Debenham JS, Rundquist PA, Seiler BD, Shelton MC, et al. Advances in cellulose ester performance and application. Prog Polym Sci. 2001;26:1605.

114. Turbak, AF, El-Kafrawy A, Snyder FW, Auerbach AP. 1981. U.S. Patent 4303252.

115. Fink HP, Weigel P, Purz HJ, Ganster J. Structure formation of regenerated cellulose materials from NMMO-solutions. Prog Polym Sci. 2001;26:1473-524.

116. Heinze T, Dicke R, Koschella A, Klohr EA, Koch W. Effective preparation of cellulose derivatives in a new simple cellulose solvent. Macromol Chem Phys. 2000. https://doi.org/10.1002/(SICI)1521-3935(20000301)201:6<627: AID-MACP627>3.0.CO;2-Y.

117. Graenacher C, Sallmann R. 1939. US patent 2179181, assigned to society to chemical industry, Basel.
118. McCorsely CC, Varga JK. 1977 US Patent 4142913, assigned to Arizona Inc.

119. Fink HP, Purz HJ, Weigel P. Strukturelle Aspekte neuer Cellulosemateriaalien Das Paiper. 1997;51:643-52.

120. Zhang H, Wu J, Zhang J, He J. 1-allyl-3-methylimidazolium chloride room temperature ionic liquid: a new and powerful nonderivatizing solvent for cellulose. Macromolecules. 2005. https://doi.org/10.1021/ma0505676.

121. Cao Y, Wu J, Zhang J, Li H, Zhang Y, He J. Room temperature ionic liquids (RTILS): a new and versatile platform for cellulose processing and derivatization. Chem Eng J. 2009. https://doi.org/10.1016/j.cej.2008.11.011.

122. Cai J, Zhang L. Unique gelation behavior of cellulose in $\mathrm{NaOH} /$ urea aqueous solution. Biomacromolecules. 2006a. https://doi.org/10.1021/bm0505585.

123. Cai J, Zhang L. Unique geletion behaviour of cellulose in $\mathrm{NaOH} /$ urea auqeous solution. Biomacromolecules. 2006b. https://doi.org/10.1021/ bm0505585.

124. Deng J, He Q, Wu Z, Yang W. Using glycidyl methacrylate as crosslinking agent to prepare thermosensitive hydrogels by a novel one-step method. J Polym Sci Part A: Polym Chem. 2008. https://doi.org/10.1002/pola.22554.

125. Guo K, Chu CC. Synthesis and characterization of novel biodegradable unsaturated poly (ester amide)/poly (ethylene glycol) diacrylate hydrogels. J Polym Sci Part A: Polym Chem. 2005;43:3932.

126. Bourges X, Weiss P, Daculsi G, Legeay G. Synthesis and general properties of silated-hydroxypropyl methylcellulose in prospect of biomedical use. Adv Colloid Interf Sci. 2002. https://doi.org/10.1016/S0001-8686(02)00035-0.

127. Trojani C, Weiss P, Michiels JF, Vinatier C, Guicheux J, Daculsi G, et al. Threedimensional culture and differentiation of human osteogenic cells in an injectable hydroxypropylmethylcellulose hydrogel. Biomaterials. 2005. https://doi.org/10.1016/j.biomaterials.2005.02.001.

128. Yang MJ, Chen CH, Lin PJ, Huang CH, Chen W, Sung HW. Novel method of forming human embryoid bodies in a polystyrene dish surface-coated with a temperature-responsive methylcellulose hydrogel. Biomacromolecules. 2007a. https://doi.org/10.1021/bm0704166.

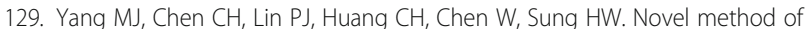
forming human Embryoid bodies in a polystyrene dish surface-coated with a emperature-responsive methylcellulose hydrogel. Biomacromolecules. 2007b. https://doi.org/10.1021/bm0704166.

130. Dang DL, Dang VL. Chitosan-carboxymethylcellulose hydrogels as supports for cell immobozation. J Macromol Sci: Pure Appl Chem. 1996;33:1875.

131. Faroongsarng $D$, Sukonrat $P$. Thermal behavior of water in the selected starch-and cellulose-based polymeric hydrogels. Int J Pharm. 2008. https:// doi.org/10.1016/j.ijpharm.2007.10.022.

132. Hebeish A, Higazy A, El-Shafei A, Sharef S. Synthesis of carboxymethyl cellulose (CMC) and starch-based hybrids and their applications in flocculation and sizing. Carbohydr Polym. 2010. https://doi.org/10.1016/j. carbpol.2009.07.022.

133. Isklan N. Controlled release of insecticide carboxyl from sodium alginate, sodium alginate/gelatin, and sodium alginate/sodium carboxymethyl cellulose blend beads cross-linked with glutaraldehyde. J Appl Polym Sci. 2005. https://doi.org/10.1002/app.22012.

134. Liang HF, Hong MH, Ho RM, Chung $\mathrm{CK}$, Lin YH, Chen $\mathrm{CH}$, et al. Novel method using a temperature-sensitive polymer (methylcellulose) to thermally gel aqueous alginate as a $\mathrm{pH}$-sensitive hydrogel. Biomacromolecules. 2004. https://doi.org/10.1021/bm049813w.

135. Sannino A, Madaghiele M, Conversano F, Mele G, Maffezzoli A, Netti PA, et al. Cellulose derivative-hyaluronic acid-based microporous hydrogels cross-linked through divinyl sulfone to modulate equilibrium sorption capacity and network stability. Biomacromolecules. 2004. https://doi.org/10.1021/bm0341881.

136. Li N, Bai R. Copper adsorption on chitosan-cellulose hydrogel beads: behaviors and mechanisms. Sep Purif Technol. 2005. https://doi.org/10. 1016/j.seppur.2004.08.002.

137. Zhao L, Mitomo H. Adsorption of heavy metal ions from aqueous solution onto chitosan entrapped CM-cellulose hydrogels synthesized by irradiation. J Appl Polym Sci. 2008. https://doi.org/10.1002/app.28718.

138. Chang C, Peng J, Zhang L, Pang DW. Strongly fluorescent hydrogels with quantum dots embedded in cellulose matrices. J Mater Chem. 2009. https:// doi.org/10.1039/B908835K

139. Fellah $B H$, Weiss $P$, Gauthier $O$, Rouillon T, Piler $P$, Daculsi $G$, et al. Bone Repair Using a New Injectable Self-Cross linkable Bone Substitute. J Ortho Res. 2006. https://doi.org/10.1002/jor.20125.

140. Hutchens SA, Benson RS, Evans BR, O'Neill HM, Rawn CJ. Biomimetic synthesis of calcium-deficient hydroxyapatite in a natural hydrogel. Biomaterials. 2006. https://doi.org/10.1016/j.biomaterials.2006.04.032. 
141. Park TJ, Lee SH, Trevor JS, Martin JG, Mousa SA, Snezhkova EA, et al. Heparin-cellulose-charcoal composite for drug detoxification prepared using room temperature ionic liquids. Chem Commun. 2008. https://doi.org/10. 1039/B809791G.

142. Xiong G, Luo H, Gu F, Zhang J, Hu D, Wan Y. A novel in vitro threedimensional macroporous scaffolds from bacterial cellulose for culture of breast cancer cells. J Biomater Nanobiotechnol. 2013. https://doi.org/10. 4236/jbnb.2013.44040.

143. Czaja WK, Young DJ, Kawecki M, Brown RM Jr. The future prospects of microbial cellulose in biomedical applications. Biomacromolecules. 2007. https://doi.org/10.1021/bm060620d.

144. Sannino A, Pappada S, Madaghiele M, Maffezzoli A, Ambrosio L, Nicolais L. Crosslinking of cellulose derivatives and hyaluronic acid with watersoluble carbodiimide. Polymer. 2005. https://doi.org/10.1016/j.polymer. 2005.10.048.

145. Modulevsky DJ, Cuerrier CM, Pelling AE. Biocompatibility of subcutaneously implanted plant-derived cellulose biomaterials. PLoS One. 2016. https://doi. org/10.1371/journal.pone.0157894.

146. Liu Y, Wang H, Yu G, Yu Q, Li B, Mu X. A novel approach for the preperation of nanocrystalline cellulose by using phosphotungstic acid. Carbohydr Polym. 2014. https://doi.org/10.1016/j.carbpol.2014.04.040

147. Bhattarai N, Li Z, Edmondson D, Zhang M. Alginate-based nanofibrous scaffolds: structural, mechanical, and biological properties. Adv Mater. 2006. https://doi.org/10.1002/adma.200502537.

148. Van Vlierberghe S, Dubruel P, Schacht E. Biopolymer-based hydrogels as scaffolds for tissue engineering applications: a review. Biomacromolecules. 2011. https://doi.org/10.1021/bm200083n.

149. Shah R, Vyroubal R, Fei H, Saha N, Kitano T, Saha P. Preparation of bacterial cellulose based hydrogels and their viscoelastic behavior. AIP Conf Proc. 2015:1662:040007.

150. Nakayama A, Kakugo A, Gong JP, Osada Y, Takai M, Erata T, et al. High mechanical strength double-network hydrogel with bacterial cellulose. Adv Funct Mater. 2004;14:1124-8.

151. Haroun AA, Gamal-Eldeen A, Harding DRK. Preparation, characterization and in vitro biological study of biomimetic three-dimensional gelatinmontmorillonite/cellulose scaffold for tissue engineering. J Mater Sci Mater Med. 2009;20:2527-40.

152. Woehl MA, Canestraro CD, Mikowski A, Sierakowski MR, Ramos LP, Wypych F. Bionanocomposites of thermoplastic starch reinforced with bacteria cellulose nanofibres: effect of enzymatic treatment on mechanical properties. Carbohydr Polym. 2010;80:866-73.

153. Khan S, Ul-Islam M, Ikram M, Ullah MW, Israr M, Subhan F, et al. Threedimensionally microporous and highly biocompatible bacterial cellulosegelatin composite scaffolds for tissue engineering applications. RSC Adv. 2016;6:110840-9.

154. Mohamad N, Amin MCIM, Pandey M, Ahmad N, Rajab NF. Bacterial cellulose/acrylic acid hydrogel synthesized via electron beam irradiation: accelerated burn wound healing in an animal model. Carbohydr Polym. 2014:114:312-20.

155. Fang Q, Zhou X, Deng W, Zheng Z, Liu Z. Freestanding bacterial cellulosegraphene oxide composite membranes with high mechanical strength for selective ion permeation. Sci Rep. 2016;6:33185.

156. Qiu Y, Qiu L, Cui J, Wei Q. Bacterial cellulose and bacterial cellulose-vaccarin membranes for wound healing. Mater Sci Eng C. 2016;59:303-9.

157. de Oliveira SA, da Silva BC, Riegel-Vidotti IC, Urbano A, de Sousa Faria-Tischer PC, Tischer CA. Production and characterization of bacterial cellulose membranes with hyaluronicn acid from chicken comb. Int J Biol Macromol. 2017;97:642-53.

158. Daltro P, Daltro G, De Oliveira G, Basmaji P, Guastaldi A. Hydrogel and bacterial cellulose mats behavior with calcium phosphate deposition. In: Front Bioeng Biotechnol conference abstract: 10th World Biomaterials Congress 17-22 May; 2016. https://doi.org/10.3389/conf.FBIOE.2016.01.02697.

159. Li X, Wan W, Panchal CJ. US Patent US894033727, 2015

160. Buyanov AL, Revel'skaya LG, Kuznetzov YP, Shestakova AS. Cellulosepoly (acrylamide or acrylic acid) interpenetrating polymer network membranes for the pervaporation of water-ethanol mixtures. J Appl Polym Sci. 1998;69:761-9.

161. Buyanov AL, Gofman IV, Revel'skaya LG, Khripunov AK, Tkachenko AA. Anisotropic swelling and mechanical behavior of composite bacterial cellulose-poly(acrylamide or acrylamide-sodium acrylate) hydrogels. J Mech Behav BioMed Mater. 2010. https://doi.org/10.1016/j.jmbbm.2009.06.001.
162. Ahn SJ, Shin YM, Kim SE, Jeong SI, Jeong JO, Park JS, et al. Characterization of hydroxyapatite-coated bacterial cellulose scaffold for bone tissue engineering. Biotechnol Bioprocess Eng. 2015;20:948-55.

163. Ran J, Jiang $P$, Liu S, Sun G, Yan $P$, Shen $X$, et al. Constructing multicomponent organic/inorganic composite bacterial cellulose-gelatin/ hydroxyapatite double-network scaffold platform for stem cell-mediated bone tissue engineering. Mater Sci Eng C. 2017;78:130-40.

164. Jung R, Kim Y, Kim HS, Jin HJ. Antimicrobial properties of hydrated cellulose membranes with silver nanoparticles. J Biomater Sci Polym Ed. 2009. https:/ doi.org/10.1163/156856209X412182.

165. Chen YM, Xi TF, Zheng YD, Wan YZ. In Vitro Cytotoxicity Study of the NanoHydroxyapatite/Bacterial Cellulose Nanocomposites. In: Materials Research, Parts 1 and 2. Gu ZW et al., editors. Portland; 2009.p.1011-1016.

166. Muller FA, Muller L, Hofmann I, Greil P, Wenzel MM, Staudenmaier R. Cellulose-based scaffold materials for cartilage tissue engineering. Biomaterials. 2006;27:3955-63.

167. Millon LE, Wan WK. The polyvinyl alcohol-bacterial cellulose system as a new nanocomposite for biomedical applications. J Biomed Mater Res Part B Appl Biomater. 2006a. https://doi.org/10.1002/jbm.b.30535.

168. Millon LE, Wan WK. The polyvinyl alcohol-bacterial cellulose system as a new nano composite for biomedical applications. J Biomed Mater Res Part B. 2006b;79:245-53.

169. Millon LE, Mohammadi H, Wan WK. Anisotropic polyvinyl alcohol hydrogel for cardiovascular applications. J Biomed Mater Res Part B. 2006;7:305-11.

170. Wang J, Gao C, Zhang Y, Wan Y. Preparation and in vitro characterization of BC/PVA hydrogel composite for its potential use as artificial cornea biomaterial. Mater Sci Eng C. 2010. https://doi.org/10.1016/j.msec.2009.10.006.

171. Wang J, Gao C, Zhang Y, Wan Y. Preparation and in vitro characterization of BC/PVA hydrogel composite for its potential use as artificial cornea biomaterial. Mater Sci Eng C. 2010;30:214-8.

172. Lina F, Yue Z, Jin Z, Guang Y. Bacterial cellulose for skin repair materials, chapter 13. In: Fazel RR, editor. Biomedical engineering frontiers and challenges. London: In Tech; 2011. https://doi.org/10.5772/24323.

173. Moraes PRFDS, Saska S, Barud H, Lima LRD, Martins VDCA, Plepis AMDG, et al. Bacterial cellulose/collagen hydrogel for wound healing. Mater Res. 2016;19:106-16.

174. Gupta A, Low WL, Radecka I, Britland ST, Mohd Amin MCl, Martin C. Characterisation and in vitro antimicrobial activity of biosynthetic silverloaded bacterial cellulose hydrogels. J Micro Encapsul. 2016;33:725-34.

175. Mohite BV, Patil SV. In situ development of nanosilver-impregnated bacterial cellulose for sustainable released antimicrobial wound dressing. J Appl Biomater Funct Mater. 2016;14:e53-8.

176. Avery NC, Sims TJ, Warkup C, Bailey AJ. Collagen cross-linking in porcine $m$ longissimus lumborum: absence of a relationship with variation in texture at pork weight. Meat Sci. 2007. https://doi.org/10.1016/0309-1740(95)00021-6.

177. Svensson A, Nicklasson E, Harrah T, Panilaitis B, Kaplan DL, Brittberg M, et al. Bacterial cellulose as a potential scaffold for tissue engineering of cartilage. Biomaterials. 2005. https://doi.org/10.1016/j.biomaterials.2004.02.049.

178. Yadav V, Sun L, Panilaitis B, Kaplan DL. In vitro chondrogenesis with lysozyme susceptible bacterial cellulose as a scaffold. J Tissue Eng Regen Med. 2013. https://doi.org/10.1002/term.

179. Andersson J, Stenhamre H, Backdahl H, Gatenholm P. Behaviour of human chondrocytes in engineered porous bacterial cellulose scaffolds. J Biomed Mater Res A. 2010. https://doi.org/10.1002/jbm.a.32784

180. Shah J, Brown MRJR. Towards electronic paper displays made from microbial cellulose. Appl Microbiol Biotechnol. 2005. https://doi.org/10.1007/ s00253-004-1756-6.

181. Sannino A, Demitri C, Madaghiele M. Biodegradable cellulose-based hydrogels: design and applications. Materials. 2009. https://doi.org/10.3390/ ma2020353.

182. Barman A, Das M. Cellulose-Based Hydrogels for Pharmaceutical and Biomedical Applications. In: Mondal MIH, editor. Cellulose-based Superabsorbent Hydrogels: Springer Nature; 2018. p. 1-28. https://doi.org/ 10.1007/978-3-319-76573-0 37-1.

183. Legeza VI, Galenko-Yaroshevskii VP, Zinov'ev EV, Paramonov BA, Kreichman GS, Turkovskii II, et al. Effects of new wound dressings on healing of thermal burns of the skin in acute radiation disease. Bull Exp Biol Med. 2004. https:// doi.org/10.1007/s10517-005-0029-4.

184. Wiegand C, Elsner P, Hipler UC, Klemm D. Protease and ROS activities influenced by a composite of bacterial cellulose and collagen type I in vitro. Cellulose. 2006. https://doi.org/10.1007/s10570-006-9073-0. 
185. Baptista A, Ferreira I, Borges J. Cellulose-Based Bioelectronic Devices. InTech. 2013; p.67-82.

186. Czaja W, Krystynowicz A, Bielecki S, Brown R Jr. Microbial cellulose - the natural power to heal wounds. Biomaterials. 2006. https://doi.org/10.1016/j. biomaterials.2005.07.035.

187. Wei B, Yang G, Hong F. Preparation and evaluation of a kind of bacterial cellulose dry films with antibacterial properties. Carbohydr Polym. 2011. https://doi.org/10.1016/j.carbpol.2010.12.017.

188. Almeida IF, Pereira T, Silva NHCS, Gomes FP, Silvestre AJD, Freire CSR, et al Bacterial cellulose membranes as drug delivery systems: an in vivo skin compatibility study. Eur J Pharm biopharma. 2014. https://doi.org/10.1016/j. ejpb.2013.08.008.

189. Yoshino A, Tabuchi M, Uo M, Tatsumi H, Hideshima K, Kondo S, et al. Applicability of bacterial cellulose as an alternative to paper points in endodontic treatment. Acta Biomater. 2013. https://doi.org/10.1016/j.actbio. 2012.12.022

190. Salata LA, Hatton PV, Devlin AJ, Craig GT, Brook IM. In vitro and in vivo evaluation of e-PTFE and alkali-cellulose membranes for guided bone regeneration. Clin Oral Implants Res. 2001. https://doi.org/10.1034/j.16000501.2001.012001062.x.

191. Vielreicher M, Kralisch D, Volki S, Sternal F, Arkudas A, Friedrich O. Bacterial nanocellulose stimulates mesenchymal stem cell expansion and formation of stable collagen-I networks as a novel biomaterial in tissue engineering. Scientific Reports. 2018. https://doi.org/10.1038/s41598-018-27760-z.

192. Orlando I, Roy I. Cellulose-based hydrogels for wound healing. In: Mondal MIH, editor. Cellulose-based Superabsorbent Hydrogels: Springer Nature; 2018. p. 1-18. https://doi.org/10.1007/978-3-319-76573-0_38-1.

193. Winter GD. Formation of the scab and the rate of epithelization of superficial wounds in the skin of the young domestic pig. Nature. 1962. https://doi.org/10.1038/193293a0.

194. Sinko PJ, Stein S, Menjoge AR, Gunaseelan S, Anumolu SN, Navath R. Dressing compositions and methods. Patent WO2008133918, 2008.

195. St. John JV, Moro DG. Hydrogel wound dressing and biomaterials formed in situ and their uses. Patent WO2008070270(A2), 2008.

196. Zhanshan Y, Zhigao R, Ling Y, Shuqin Y, Nankang Z. Medical hydrogel wound dressing and preparation method thereof. Patent CN101293110(A), 2008.

197. Burd A, Tsang MW. Wound healing dressings and methods of manufacturing the same. Patent WO2008101417(A1), 2008.

198. Laluppa JA, McAdams TA, Papoutsakis TE, Miller WM. Culture materials affect ex vivo expansion of hematopoietic progenitor cells. Biomed Mater Res. 1997. https://doi.org/10.1002/(SICI)1097-4636(19970905)36:3<347::AIDJBM10>3.0.CO;2-B.

199. Cullen B, Watt PW, Lundqvist C, Silcock D, Schmidt RJ, Bogan D, et al. The role of oxidized regenerated cellulose/collagen in chronic wound repair and its potential mechanism of action. Int J Biochem Cell Biol. 2002. https://doi. org/10.1016/S1357-2725(02)00054-7.

200. Chen W, Yu H, Liu Y, Hai Y, Zhang M, Chen P. Isolation and characterization of cellulose nanofibers from four plant cellulose fibers using a chemicalultrasound process. Cellulose. 2011. https://doi.org/10.1007/s10570-011-9497-z.

201. Abe K, Yano H. Comparison of the characteristics of cellulose microfibril aggregates isolated from fiber and parenchyma cells of Moso bamboo (Phyllostachys pubescens). Cellulose. 2010. https://doi.org/10.1007/s10570009-9382-1.

202. Kumar PS, Ramakrishnan K, Kirupha SD, Sivanesan S. Thermodynamics and kinetic studies of cadmium adsorption from aqueous onto rice husk. Braz Chem Eng. 2010. https://doi.org/10.1590/50104-66322010000200013.

203. Paton D. Cellulose from apple tissue: isolation, purification and chemical modification. Can Inst Food Sci Technol. 1974;7:61-4.

204. Lu H, Gui Y, Zheng L, Liu X. Morphological, crystalline, thermal and physicochemical properties of cellulose nanocrystals obtained from sweet potato residue. Food Res Int. 2013. https://doi.org/10.1016/j.foodres.2012.10.013.

205. De Morais TE, Correa AN, Manzoli A, de Lima LF, de Oliveria CR. Cellulose nanofibers from white and naturally colored cotton fibers. Cellulose. 2010 https://doi.org/10.1007/s10570-010-9403-0

206. Israel AU, Obot IB, Umoren SA, Mkpenie V, Asuquo JE. Production of cellulosic polymers from agricultural waste. E-J Chem. 2008;5:81-5.

207. Caetano NS, VFM S, Mata TM. Valorization of coffee grounds for biodiesel production. Chem Eng Trans. 2012. https://doi.org/10.3303/CET1226045.

208. Loelovich M, Leykin A. Structural investigation of various cotton fibers and cotton celluloses. BioResources. 2008:3:170-7.

\section{Ready to submit your research? Choose BMC and benefit from:}

- fast, convenient online submission

- thorough peer review by experienced researchers in your field

- rapid publication on acceptance

- support for research data, including large and complex data types

- gold Open Access which fosters wider collaboration and increased citations

- maximum visibility for your research: over $100 \mathrm{M}$ website views per year

At $\mathrm{BMC}$, research is always in progress.

Learn more biomedcentral.com/submissions 